\title{
CRVENA I CRNA HRVATSKA U DUGOROČNOJ PERSPEKTIVI
}

\author{
Marko Grdešić \\ Fakultet političkih znanosti \\ Sveučilište u Zagrebu \\ E-mail: marko.grdesic@fpzg.hr
}

https://doi.org/ 10.20901/an.18.08

Izvorni znanstveni rad Zaprimljeno: 10. 6. 2021. Prihvaćeno: 12. 11. 2021.

Sažetak Jedna od bolje utvrđenih činjenica hrvatske politike jest geografska podjela na sjeverozapadni dio zemlje koji glasa za lijeve opcije i jugoistočni dio zemlje koji glasa za desne opcije. Hrvatska u tom pogledu nije iznimka s obzirom na to da više zemalja u regiji i šire dijeli isto obilježje geografskog grupiranja različitih vrsta političkih identiteta. Koji bi dugoročni faktori mogli objasniti taj prostorni raspored, podjelu zemlje na "crvenu" i "crnu" Hrvatsku? Ovaj rad koristi kvantitativnu analizu podataka na razini geografski definiranih jedinica kako bi istražio efekt triju grupa faktora: (1) razvojnog naslijeđa socijalističke Jugoslavije kakvo je ono bilo u trenutku raspada te države, (2) dubokih strukturnih, ekonomskih i demografskih promjena koje su se dogodile od kraja socijalističke Jugoslavije do danas i (3) dugoročnog naslijeđa Drugog svjetskog rata (1941-1945) i Domovinskog rata (1991-1995).

Ključne riječi prostorna analiza, Hrvatska, izbori, političke stranke, politička geografija, općine, politički identiteti

\section{Uvod $^{1}$}

Jedno od najpouzdanijih obilježja hrvatske politike jest geografska distribucija političkih identiteta. U osnovi, sjeverozapadni dio zemlje glasa za stranke i političke kandidate lijevog centra i ljevice, dok jugoistočni dio glasa za opcije desnog centra i desnice. Politički identiteti tih lokaliteta relativno su jasno obojani. Moguće je, dakle, govoriti o postojanju "crvene" i "crne" Hrvatske (Grdešić, 2013). Alternativno, ukoliko se usvoji praksa iz drugih europskih zemalja u kojima se glavna umjerena konzervativna stranka obično veže uz plavu boju, a glavna umjerena socijaldemokratska stranka uz crvenu boju, onda je moguće govoriti o postojanju "crvene" i "plave" Hrvatske (Šalaj, 2014). Konkretnije, Zagorje, Međimurje, Zagreb i okolica, Istra, Kvarner te neki dijelovi Dalmacije poput otoka, skloniji su lijevim opcijama. S druge pak strane, Slavonija, Baranja, Banija, Lika te neki dijelovi Dalmacije, posebno dalmatinsko zaleđe, skloniji su desnim opcijama.

Ovaj se rad bavi dugoročnim faktorima pomoću kojih bi se taj geografski raspored lokalnih političkih identiteta mogao objasniti. U pristupanju tom problemu pretpostavlja se da su ti politički identiteti ili političke "atmosfere" koje postoje u nekoj sredini fenomen koji sam po sebi zaslužuje pažnju. Naime, neki radovi ovog tipa upozoravaju čitatelja da analiza geografskih jedinica, kao što su općine i gra-

\footnotetext{
Autor se zahvaljuje uredniku i recenzentima na korisnim sugestijama.
} 
dovi, ne može zamijeniti analizu stavova samih pojedinaca koji u tim sredinama žive (Grdešić, 2013: 187; Henjak, 2019: 421). To je, naravno, točno. Međutim, ne treba gledati na analizu geografskih jedinica kao na "second-best" analizu. Lokalne "političke atmosfere" su varijabla koja je sama po sebi relevantna i zaslužuje pažnju. Naime, zna se da su neki dijelovi Hrvatske naprosto "crveni", a drugi "crni". U Puli je "u zraku" određena politička atmosfera, kao i u Imotskom, ali su te političke atmosfere suprotnog političkog predznaka. Iako je riječ o relativno pouzdanom nalazu koji prati hrvatsku politiku od početaka višestranačkog razdoblja, sami izvori tih prostorno utemeljenih identiteta nisu dublje istraženi. Drugim riječima, premda je riječ o "općem mjestu hrvatske politike" (Šalaj, 2014), nije sasvim jasno kako je došlo do tog rasporeda političkih snaga u geografskom prostoru.

Ovaj se rad bavi determinantama tog političkog rasporeda u dugom roku. Kako je povijesno iskustvo oblikovalo političke identitete pojedinih lokalnih sredina $\mathrm{u}$ Hrvatskoj? Prostorni pristup pokušava te podjele promatrati u pravom geografskom prostoru, a ne samo kroz osobne stavove pojedinaca. Do sada već postoji više doprinosa koji na ovaj ili onaj način pokušavaju promatrati geografsku utemeljenost hrvatske politike (Grdešić, 2013; Glaurdić i Vuković, 2015; Glaurdić i Vuković, 2016a; 2016b; Marcelić, 2015; Henjak, 2019; Institut sinergije znanosti i društva, 2014). Ovaj se rad pridružuje tim doprinosima te pokušava pronaći one faktore koji su u dugoročnoj perspektivi oblikovali geografske političke identitete koje možemo vidjeti u svakodnevici.

Rad donosi nekoliko zaključaka. Prvo, efekt naslijeđa socijalističkog razvoja relevantan je i danas. One sredine koje imaju "tradiciju" ekonomske nerazvijenosti, pasivnosti i zapuštenosti još iz vremena socijalističke Jugoslavije, danas su sklonije desnim političkim opcijama. One sredine koje su tada bile više sekularno (ateistički) orijentirane i dan-danas se u većoj mjeri okreću ljevici, a ne desnici. Također, one sredine koje su "povijesno" srpske, tj. one sredine u kojima je živio veći postotak srpskog stanovništva i na recentnim su izborima sklonije ljevici. Kada je riječ o učinku dubokih tranzicijskih promjena od početka devedesetih godina do danas, valja istaknuti da su povećanje u ekonomskoj pasivnosti i dezindustrijalizacija na lokalnoj razini opet povezani s jačim desnim političkim identitetitima. S druge pak strane, suprotno vrijedi za povećanje u udjelu ateističkog stanovništva: ono jača ljevicu. Još valja spomenuti i to da je veliko smanjenje u udjelu srpskog stanovništva povezano s boljim rezultatima desnice, tj. $s$ jačim lokalnim desnim političkim identitetima.

Prema tome, "crna" Hrvatska se veže uz "tradiciju" ekonomske nerazvijenosti, uz daljnje ekonomsko propadanje u posljednjih nekoliko desetljeća, uz etničku homogenost i religioznost. S druge strane, "crvena" Hrvatska se veže uz etničku heterogenost, sekularizaciju i nešto bolji ekonomski položaj. Kada je riječ o učinku ratova iz dvadesetog stoljeća, veća izloženost Domovinskom ratu povezana je s jačim desnim političkim identitetima i slabijim lijevim identitetima. Učinci varijabli pomoću kojih se mjerilo naslijeđe Drugog svjetskog rata uglavnom su slabi. Iako lokalne sredine "pamte", to sugerira da je sjećanje na taj rat uvelike oslabilo.

\section{Crvena i crna Hrvatska u dugoročnoj perspektivi}

Dosadašnja se literatura o političkim rascjepima u Hrvatskoj uglavnom orijentirala na stavove pojedinačnih ispitanika. Pri tome je već više puta detektirana slična struktura političkih sukoba u Hrvatskoj (Grdešić i dr., 1991; Milas i Rimac, 1994; Zakošek, 1994; 1998; Šiber, 1997; 1998; Henjak, 2005; Bagić, 2007; Raos, 2020). 
Osnovna podjela je u tome kakve stavove građani imaju prema pitanjima kao što su tradicija, Drugi svjetski rat, Domovinski rat, Crkva itd. Drugim riječima, os lijevo-desno je u Hrvatskoj postavljeno na pitanjima svjetonazora, religije i tradicije, a manje na ekonomskim, klasnim i distributivnim pitanjima. Takva pitanja su uglavnom od sekundarne važnosti, premda to neki tumače kao neuspjeh hrvatske demokracije i vodećih političkih stranaka (Dolenec, 2012).

Za veći se dio razdoblja od samostalnosti moglo pretpostaviti da dvije glavne stranke - SDP na lijevoj strani političkog spektra i HDZ na desnoj strani - mogu poslužiti kao sidro za razumijevanje te podjele na "crvenu" i "crnu" Hrvatsku, s obzirom na to da bi te dvije stranke zajedno prikupile oko dvije trećine glasova na izborima (Raos, 2015: 9). Stabilnost političkog natjecanja očitovala se u sklonosti birača da formiraju dugoročnu povezanost sa "svojom" strankom koju čak i promjene u politikama i programima ne bi pokolebale (Čular, 2004; Henjak, 2008). Posljednjih nekoliko godina, međutim, nove su političke opcije, kako na desnici tako i na ljevici, dovele u pitanje stabilnost ovog obrasca (Raos, 2019; Henjak, 2019). Sve je više naznaka da se politički teren mijenja te da danas dvama glavnim strankama konkuriraju nove stranke na oba pola političkog spektra. Rast izazivača je i širi trend u istočnoj Europi, gdje razočarani birači traže nove političke aktere kojima će pružiti priliku (Pop-Eleches 2010). Prema tome, bilo kakva operacionalizacija koncepta "crvene" i "crne" Hrvatske može započeti sa "stožernim" strankama, SDP-om i HDZ-om, ali u daljnjim koracima mora obuhvatiti i druge opcije kako na lijevom tako i na desnom polu.

Gdje tražiti dugoročne izvore lokalnih političkih identiteta ili lokalnih političkih atmosfera? Ovaj će rad promatrati tri različita skupa mogućih objašnjenja. Prvo, treba istražiti strukturne faktore koje je Hrvatska naslijedila iz razdoblja socijalističke Jugoslavije, dakle faktore koji su nastali nakon četiri desetljeća socijalističkog razvoja. Drugo, treba istražiti strukturne faktore koji su se formirali tijekom tranzicije od jugoslavenskog socijalizma ka novom modelu veće tržišne otvorenosti, političkog pluralizma, ali i veće etničke homogenosti. Dakle, treba promatrati i apsolutne razine i stope promjene jer i jedno i drugo može biti relevantno za ljudsku percepciju, kao što sugerira bihevioralna ekonomija (Kahneman i Tversky, 1979). I treće, treba istražiti dugoročne faktore koji su povezani s ratnim epizodama kojih je nažalost na ovom geografskom prostoru bilo više tijekom dvadesetog stoljeća. Uzeti zajedno, ova tri skupa čimbenika omogućavaju da se operacionalizira učinak dugog roka.

Socijalistička Jugoslavija je tijekom više od četiri desetljeća svog postojanja temeljito izmijenila ekonomski i društveni kontekst u kojem ljudi žive. Nastanak značajnog industrijskog sektora, širenje obrazovanosti kroz populaciju, ali i kulturna promjena u skladu sa socijalističkim svjetonazorom režima ostavili su traga i u geografskom prostoru. Međutim, taj je otisak modernizacijskog pothvata socijalističke Jugoslavije bio nejednako raspoređen u prostoru, pa se varijacija koja postoji u strukturnim faktorima može dovesti u vezu s političkim identitetima koji su formirani nakon što je socijalistički režim prestao postojati. Naravno, socijalistički razvoj nije svuda uspjevao izmijeniti ranije formirane putanje razvoja. Prema tome, ako je neka sredina bila nerazvijena u trenutku raspada socijalističke Jugoslavije to može biti posljedica nerazvijenosti koja seže mnogo dalje u povijest, do prve Jugoslavije ili čak do Austro-Ugarske. Međutim, istovremeno valja priznati da je socijalistička Jugoslavija ipak trajala više od četiri desetljeća pa relativni (ne)uspjeh neke sredine ipak treba najprije vezati uz taj režim, a tek zatim za starije režime. 
Za očekivati je, prema tome, da će one sredine koje su bolje stajale za vrijeme socijalizma biti sklonije lijevim opcijama, dok će se one sredine koje su tada lošije stajale, okrenuti desnici. Naime, i drugdje se ovaj obrazac pojavljuje relativno često: kako neka sredina biva siromašnija, tako ona postaje sklonija glasati za desnicu. U takvim se slučajevima često govori o stanovništvu koje je politički "napušteno" i "zapušteno" (Ford i Goodwin, 2014; Watson, 2018). Takve se sredine okreću ponekada i veoma radikalnoj desnici (Jennings i Stoker, 2016; Ivaldi, Lanzone i Woods, 2017; Ulrich-Schad i Duncan, 2018; McQuarrie, 2017). Doduše, neke su analize sugerirale da se u istočnoj Europi "gubitničke" sredine okreću lijevim strankama jer se desne stranke vežu uz širi program izlaska iz komunizma i privatizacije (Tucker 2006). Premda bi se moglo očekivati da će se ekonomski gubitnici okrenuti ljevici (koja bi trebala biti zaštitnik slabijih), dosadašnje iskustvo, kako Hrvatske tako i šire, ne podržava takvo očekivanje. U istočnoj Europi položaj ljevice i desnice pak uvelike odudara od očekivanja formiranih na temelju nekadašnjih iskustava zapadnih demokracija (Tavits i Letki, 2009). Stranke koje su nastale transformacijom komunističkih partija imaju potrebu distancirati se od naslijeđa socijalističkog razdoblja pa tako iščezava najveći dio klasnog i distributivnog programa ljevice. Djelomice, takve ekonomski "zapuštene" ljude i sredine preuzima desnica.

Dakle, veća se ekonomska "zapuštenost" može dovesti u vezu s vjerojatnošću da će se neka sredina okrenuti desnim, tj. "crnim" opcijama. Ovo se može formulirati i kao hipoteza: one sredine koje imaju naslijeđe razvijenosti sklonije su razviti lijeve političke identitete, dok će sredine koje imaju naslijeđe relativne nerazvijenosti razviti desne političke identitete. Drugim riječima, dana razina lokalne razvijenosti postaje važan faktor u formiranju lokalnih političkih identiteta, bilo da je riječ o relativnoj razvijenosti ili relativnoj nerazvijenosti.

Osim određene razine razvijenosti koja je dosegnuta tijekom socijalističkog razdoblja, važna je i promjena koja se dogodila od kraja Jugoslavije do recentnih godina. Hrvatska je u posljednjih nekoliko desetljeća prošla kroz veoma burne demografske, društvene i ekonomske promjene, koje se mogu i trebaju dovesti u vezu s političkim identitetima koji postoje na lokalnoj razini. Najprije, tu je napuštanje socijalističkog ekonomskog sustava te kriza domaće industrije $u$ kontekstu privatizacije i pojačane međunarodne konkurencije. Dezindustrijalizacija je pogodila cijelu zemlju, ali ipak postoji varijacija u opsegu tih promjena na lokalnoj razini. Promjene u ekonomskim faktorima te vrste je također moguće dovesti u vezu s političkim identitetima koji postoje na lokalnoj razini.

Gore spomenuta "zapuštenost" može se, dakle, pratiti kroz prizmu ekonomske strukture te njene promjene u vremenu. Međutim, podjednako je važno obuhvatiti i obrazovanost i kulturnu promjenu. Ti su faktori pogotovo značajni s obzirom da je podjela na lijevo i desno u Hrvatskoj prije svega svjetonazorskog tipa. Relativno je dobro utemeljena činjenica da slabija obrazovanost korelira s podrškom desnici (Stubager, 2008; 2010; Inglehart i Norris, 2016; Furlong, 2019). I domaće analize geografskih aspekata hrvatske politike također su upozorile da je obrazovanost značajan faktor u oblikovanju lokalnih političkih identiteta (Vinković i Potočnik, 2013; Grdešić, 2019). Formulirano kao hipoteza: veće razine obrazovanosti dovode do veće vjerojatnosti da će se neka sredina okrenuti lijevim opcijama, a manje razine obrazovanosti dovode do veće vjerojatnosti da će se neka sredina okrenuti desim političkim opcijama.

Osim spomenutog, Hrvatska je od samostalnosti prošla i kroz veoma dramatičnu demografsku tranziciju. Tijekom i nakon Domovinskog rata ova se promjena 
ponajprije očitovala u velikoj promjeni u etničkoj kompoziciji stanovništva. Prema popisu stanovništva iz 1991. godine u Hrvatskoj je živjelo oko 78 posto Hrvata, 12 posto Srba i još dodatnih 2 posto Jugoslavena. Treba napomenuti da je u tom trenutku proces etničke homogenizacije vjerojatno već započeo jer je prema popisu iz 1981. godine bilo 75 posto Hrvata, 12 posto Srba i čak 8 posto Jugoslavena. Međutim, ratna su zbivanja drastično izmijenila ovu sliku pa je prema popisu stanovništva iz 2011. godine u Hrvatskoj živjelo 90 posto Hrvata, 4 i pol posto Srba, dok Jugoslavena više nema, osim u promilima. Prema tome, Hrvatska se transformirala u državu koja "pripada" titularnoj naciji, tj. Hrvatima (za više vidi Koska, 2012; Koska i Matan, 2017). U takvom su kontekstu pripadnici etničke manjine, a pogotovo srpske, stavljeni u poziciju da se veoma teško mogu vezati uz stranke koje u ovoj ili onoj mjeri promiču hrvatske nacionalističke narative. Ili formulirano u obliku hipoteze: veća prisutnost srpske nacionalne manjine kao najznačajnije etničke manjine bit će povezana s većom vjerojatnošću da se lokalna sredina okrene lijevim opcijama, a za manju prisutnost srpske manjine treba očekivati obratno.

Kao što je već spomenuto, ovaj rad sugerira da je potrebno trenutno postojeće političke identitete pojedinih mjesta promatrati u dugom roku. Ali koliko dugom? Postoje studije koje sugeriraju da taj dugi rok može zaista biti veoma dug. To je pogotovo slučaj kada je riječ o povijesnom naslijeđu veoma traumatičnih povijesnih epizoda kao što su ratovi. Dakle, oni lokaliteti koji su bili izloženi ratnom nasilju "pamte" te formiraju svoje kasnije političke preferencije na sukladan način. Pamćenje i njegova "teritorijalizacija" živi je predmet interesa za geografiju (npr. Hoelscher i Alderman, 2004; Jones i Garde-Hansen 2012). Primjerice, u zapadnoj Ukrajini se recentni izborni rezultati mogu povezati s time koliko je neka sredina bila izložena nasilju od strane Staljinovih sigurnosnih službi (Rozenas, Schutte i Zhukov, 2017). One sredine koje su bili izložene većem nivou nasilju sada u manjem postotku glasaju za proruske stranke. Sličan dugoročni efekt pronašla je i studija koja se bavila krimskim Tatarima koja je povezala nedavne političke stavove Tatara s deportacijama 1944. godine (Lupu i Peisakhin, 2017). Također, slično se pokazalo i u studiji koja se bavila stavovima španjolskih građana u sjeni građanskog rata i Francove diktature (Balcells, 2011). Drugim riječima, povijesna naslijeđa povezana s traumatičnim iskustvima političkog nasilja mogu suoblikovati suvremene političke identitete čak i uz veliki vremenski odmak. Međutim, točna dužina vremenskog trajanja je ipak otvoreno pitanje s obzirom da neke studije pokazuju da efekt ratnih sukoba na kasnije izborne rezultate slabi s vremenom, kao što je pokazala studija Italije (Costalli i Ruggeri, 2019).

U turbulentnoj povijesti Hrvatske u 20. stoljeću potrebno je izdvojiti dva takva događaja: Drugi svjetski rat (1941-1945) i Domovinski rat (1991-1995). Uz ta dva rata vežu se dva moguća politička identiteta, onaj crveni i onaj crni. Studije su već pokazale da veća povezanost $\mathrm{s}$ ratnim nasiljem devedesetih godina, mjereno kroz udio ratnih invalida u lokalnom stanovništvu, ima pozitivni efekt na izbornu podršku desnih političkih opcija (Glaurdić i Vuković, 2015; 2016a; 2016b). Prisutnost većeg broja ratnih invalida upućuje na veći angažman te sredine u ratnim operacijama te na dugoročno naslijeđe oružane participacije lokalnog stanovništva u ratu. Potrebno je opet testirati efekt tog fenomena, ali sada uz sličnu mjeru koja bi pratila povezanost s ratnim nasiljem za vrijeme Drugog svjetskog rata. Neke starije studije povezuju individualne političke identitete s obiteljskom poviješću pojedinaca (Šiber 1997, 1998), slično gore navedenim studijama, pa je moguće da se takvi obrasci mogu pronaći i u sredinama u kojima ti pojedinci žive. Formulirano u obliku hi- 
poteze: one sredine koje imaju značajnije naslijeđe uključenosti u Domovinski rat bi trebale biti više okrenute desnim političkim opcijama, a one sredine koje imaju značajnije naslijeđe uključenosti u Drugi svjetski rat trebale bi biti više okrenute lijevim političkim opcijama.

\section{Podaci}

Podaci za ovu analizu prikupljeni su iz više izvora. Najprije treba reći da je sama geografska organizacija zemlje doživjela velike promjene pa je današnju teritorijalnu podjelu trebalo prilagoditi nekadašnjoj. Konkretnije, Hrvatska je trenutno podijeljena na više od 550 teritorijalnih jedinica, dok je pred kraj socijalističkog razdoblja teritorijalnih jedinica, koje se koriste u službenim publikacijama proizašlim iz popisa stanovništva, bilo stotinjak. Primjerice, Istra je danas podijeljena na oko 40 općina i gradova dok je osamdesetih i početkom devedesetih prošlog stoljeća bila podijeljena na 8 općina: Buje, Buzet, Pazin, Poreč, Rovinj, Pula, Labin, Opatija. To znači da je današnje općine i gradove trebalo razmjestiti u prikladnu teritorijalnu jedinicu iz starije podjele. Nažalost, time se smanjuje broj slučajeva za kvantitativnu analizu, ali se s druge strane dobiva kontinuitet podataka kroz duže vrijeme. ${ }^{2}$

Podaci koji služe za formiranje zavisnih varijabli izborni su rezultati s više parlamentarnih izbora: 2011., 2015., 2016. i 2020. godine. Parlamentarni su izbori najvažniji izbori u zemlji s obzirom da se pomoću njih formira sastav vlade. Za posljednja se tri izbora uz postotak kojeg je osvojila lista HDZ-a i lista SDP-a koriste i podaci za nove stranke: Most, Domovinski Pokret i platformu Možemo. Riječ je o izazivačima, kako na desnici tako i na ljevici, pa se time obuhvaća širi trend slabljenja duopola dviju velikih stranaka. Osim toga, koriste se i podaci za postotak kojeg je osvojio IDS, ovisno o tome da li je ta stranka sudjelovala na izborima samostalno ili na listi koju je predvodio SDP. Postotak glasova kojeg su osvojili SDP i HDZ može poslužiti kao jedna inačica zavisne varijable, ali tim se strankama mogu dodati i lijevi (tj. desni) izazivači kako bi se dobila ukupna slika lijevog (tj. desnog) bloka. Tako se na više načina može operacionalizirati "crveno" i "crno". Svi su izborni podaci dostupni na internetskim stranicama Državnog izbornog povjerenstva (DIP, 2021).

S obzirom na to da je analiza koja se ovdje provodi opsežna, tekstu je uz šest tablica i dvije karte pridružen izdvojeni metodološki dodatak s dodatnim materijalima koji proširuju analizu za one čitatelje kojima bi to moglo biti korisno. Tablica $1 \mathrm{u}$ ovom radu prikazuje deskriptivnu statistiku za zavisne varijable. U njoj se može vidjeti koliki su postotak glasova obično osvajali HDZ i SDP na parlamentarnim izborima, od 2011. do 2020. godine. Kada se HDZ-u pridodaju njima srodne stranke na desnici, može se izračunati prosječni postotak za "desni blok", a kada se SDP-u dodaju srodne stranke na ljevici, može se izračunati postotak za "lijevi blok." Kao što se može vidjeti, HDZ je u proteklih deset godina u prosječnoj teritorijalnoj jedinici osvajao od 27 do 40 posto, a slično vrijedi i za SDP. Kada se tim strankama pridodaju njima srodne stranke, ti postoci razumljivo rastu. Karta 1 prikazuje geografski raspored postotka kojeg je desni blok (HDZ s partnerima na izbornoj listi, Domovinski pokret i Most) osvojio 2020. godine, a Karta 2 prikazuje isto za lijevi blok (SDPovu listu, tzv. Restart koaliciju, te platformu Možemo). Karte prikazuju kvartile, tj.

Popis iz 1991. godine unutar vlastite sistematizacije ponekad koristi različite jedinice. Zbog toga su Zagrebu pridodani Dugo Selo, Zaprešić, Samobor i Velika Gorica, a Splitu su pridodani Solin i Kaštela. Naime, te se općine ponekad pojavljuju u publikacijama proizašlim iz popisa, a ponekad ne. Konsolidacijom se dobiva konačni broj od 99 teritorijalnih jedinica. 
Tablica 1. Deskriptivna statistika za zavisne varijable

\begin{tabular}{|c|c|c|c|c|}
\hline & $\begin{array}{l}\text { Aritmetička } \\
\text { sredina }\end{array}$ & $\begin{array}{c}\text { Standardna } \\
\text { devijacija }\end{array}$ & Minimum & Maksimum \\
\hline \multicolumn{5}{|l|}{ Parlamentarni izbori 2011. godine } \\
\hline Postotak glasova za HDZ & 26.72 & 11.08 & 4.70 & 58.93 \\
\hline Postotak glasova za SDP-ovu koaliciju & 39.93 & 12.21 & 11.32 & 70.46 \\
\hline \multicolumn{5}{|l|}{ Parlamentarni izbori 2015. godine } \\
\hline Postotak glasova za HDZ-ovu koaliciju & 37.31 & 13.19 & 7.50 & 70.40 \\
\hline Postotak glasova za SDP-ovu koaliciju & 32.22 & 10.17 & 6.92 & 71.07 \\
\hline $\begin{array}{l}\text { Postotak glasova za desni blok } \\
\text { (HDZ-ova koalicija i Most) }\end{array}$ & 48.30 & 14.86 & 13.55 & 83.40 \\
\hline $\begin{array}{l}\text { Postotak glasova za lijevi blok } \\
\text { (SDP-ova koalicija i IDS) }\end{array}$ & 36.22 & 13.54 & 6.92 & 75.02 \\
\hline \multicolumn{5}{|l|}{ Parlamentarni izbori 2016. godine } \\
\hline Postotak glasova za HDZ-ovu koaliciju & 38.55 & 12.85 & 8.70 & 74.74 \\
\hline Postotak glasova za SDP-ovu koaliciju & 32.83 & 10.61 & 6.87 & 61.32 \\
\hline $\begin{array}{l}\text { Postotak glasova za desni blok } \\
\text { (HDZ-ovva koalicija i Most) }\end{array}$ & 47.45 & 15.22 & 12.94 & 86.29 \\
\hline $\begin{array}{l}\text { Postotak glasova za lijevi blok } \\
\text { (SDP-ova koalicija i IDS) }\end{array}$ & 36.16 & 14.07 & 6.87 & 75.40 \\
\hline \multicolumn{5}{|l|}{ Parlamentarni izbori 2020. godine } \\
\hline Postotak glasova za HDZ-ovu koaliciju & 40.83 & 11.48 & 10.86 & 65.05 \\
\hline Postotak glasova za SDP-ovu koaliciju & 27.42 & 11.67 & 3.76 & 65.60 \\
\hline $\begin{array}{l}\text { Postotak glasova za desni blok (HDZ-ova } \\
\text { koalicija, Most i Domovinski pokret) }\end{array}$ & 57.54 & 16.06 & 16.25 & 96.02 \\
\hline $\begin{array}{l}\text { Postotak glasova za lijevi blok } \\
\text { (SDP-ova koalicija i Možemo!) }\end{array}$ & 30.69 & 13.13 & 4.15 & 71.52 \\
\hline
\end{tabular}

Napomena: 99 teritorijalnih jedinica (prilagođeno na temelju popisa stanovništva iz 1991. godine)

četiri jednako brojne grupe teritorijalnih jedinica. Kao što se može vidjeti, podjela na "crni" jug i istok i na "crveni" sjever i zapad jasno je vidljiva. Geografski raspored izbornih rezultata za ranije parlamentarne izbore izgleda veoma slično.

Tablica 2 prikazuje deskriptivnu statistiku za nezavisne varijable. Kao što je već najavljeno, uzimaju se u obzir tri grupe faktora. Najprije, tu su faktori koji mjere naslijeđe socijalističke Jugoslavije. Zatim, tu su faktori koji mjere tranziciju koja se dogodila od 1991. godine. Na kraju, tu su faktori koji prate naslijeđe ratova. Kod prve je grupe faktora riječ o udjelu ekonomski uzdržavanog stanovništva u ukupnom stanovništvu, o udjelu industrijskih radnika u ukupnom stanovništvu, o udjelu srpskog stanovništva u ukupnom stanovništvu, o udjelu ateista u ukupnom stanovništvu te o udjelu stanovništva koje ima fakultetsko obrazovanje. Ekonomske i obrazovne varijable prate relativnu razvijenost neke sredine. Svjetonazorska komponenta je obuhvaćena mjerom za sekularnost (ateizam), a postotak srpskog stanovništva relevantan je s obzirom na kasnije promjene u etničkom sastavu zemlje. Izvor za sve ove podatke su različite publikacije Državnog zavoda za statistiku koje su proizašle iz popisa stanovništva 1991. godine. Uzete zajedno, ove varijable operacionaliziraju 


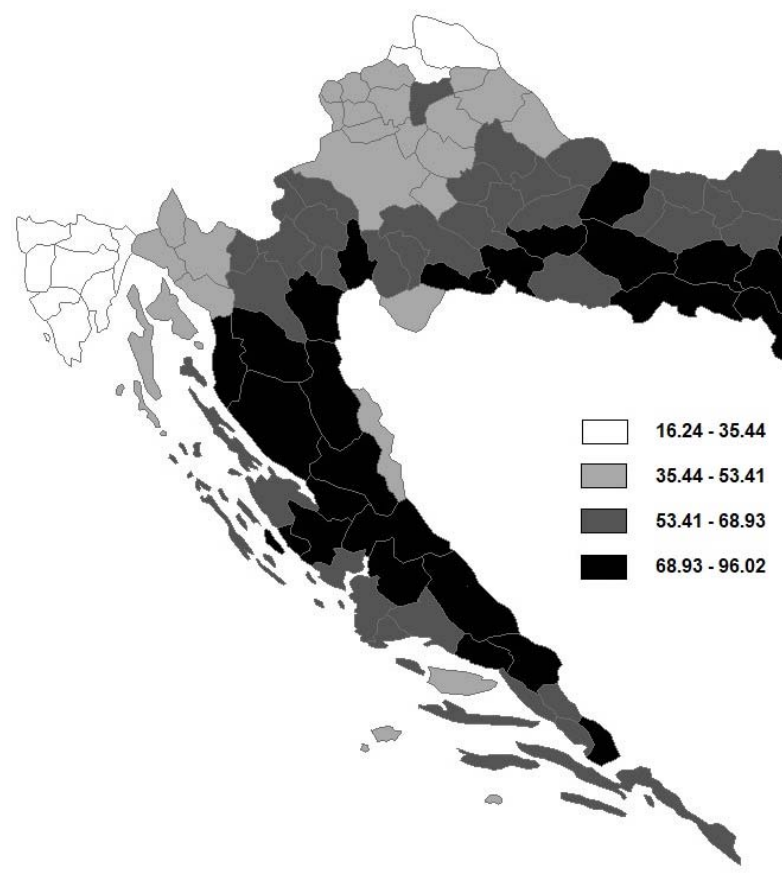

Karta 1. Postotak osvojenih glasova za Desni blok na parlamentarnim izborima 2020. godine (HDZ, Domovinski pokret, Most)

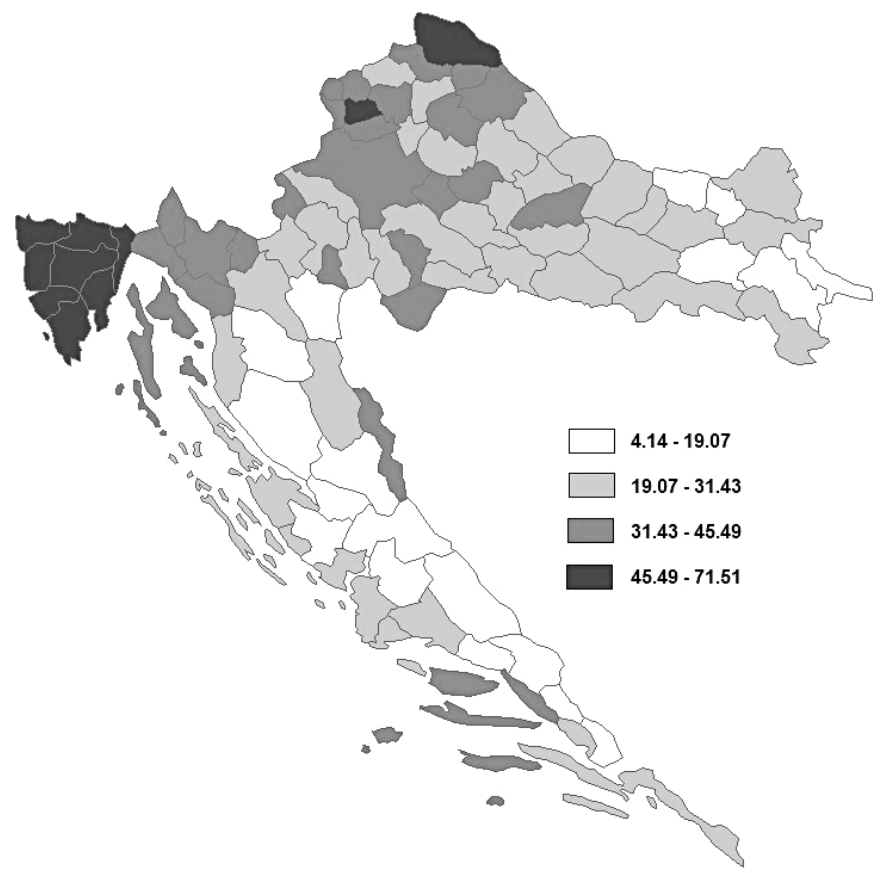

Karta 2. Postotak osvojenih glasova za Lijevi blok na parlamentarnim izborima 2020. godine (Restart koalicija - SDP i platforma Možemo!) 
Tablica 2. Deskriptivna statistika za nezavisne varijable

\begin{tabular}{|c|c|c|c|c|}
\hline & $\begin{array}{l}\text { Aritmetička } \\
\text { sredina }\end{array}$ & $\begin{array}{c}\text { Standardna } \\
\text { devijacija }\end{array}$ & Minimum & Maksimum \\
\hline \multicolumn{5}{|l|}{ Naslijeđe Jugoslavije } \\
\hline $\begin{array}{l}\text { Udio uzdržavanog stanovništva } 1991 . \\
\text { godine }\end{array}$ & 36.04 & 5.39 & 3.29 & 53.74 \\
\hline $\begin{array}{l}\text { Udio industrijskih radnika u ukupnom } \\
\text { stanovništvu 1991. godine }\end{array}$ & 7.67 & 3.81 & 0.27 & 17.46 \\
\hline $\begin{array}{l}\text { Udio Srba u ukupnom stanovništvu } \\
\text { 1991. godine }\end{array}$ & 16.98 & 24.27 & 0.10 & 97.52 \\
\hline $\begin{array}{l}\text { Udio ateista i nevjernika u ukupnom } \\
\text { stanovništvu 1991. godine }\end{array}$ & 2.94 & 2.64 & 0.19 & 14.02 \\
\hline $\begin{array}{l}\text { Udio stanovništva s fakultetskom diplo- } \\
\text { mom 1991. godine }\end{array}$ & 4.93 & 2.13 & 1.54 & 11.70 \\
\hline \multicolumn{5}{|l|}{ Tranzicija od 1991. do 2011. godine } \\
\hline $\begin{array}{l}\text { Promjena u udjelu uzdržavanog stanov- } \\
\text { ništva od 1991. do 2011. godine }\end{array}$ & 9.61 & 7.47 & -5.82 & 37.26 \\
\hline $\begin{array}{l}\text { Promjena u udjelu industrijskih radnika } \\
\text { od 1991. do 2011. godine }\end{array}$ & -1.46 & 3.38 & -9.38 & 8.52 \\
\hline $\begin{array}{l}\text { Promjena u udjelu Srba od 1991. do } \\
\text { 2011. godine }\end{array}$ & -9.02 & 13.43 & -52.95 & 3.05 \\
\hline $\begin{array}{l}\text { Promjena u udjelu ateista i nevjernika od } \\
\text { 1991. do 2011. godine }\end{array}$ & -0.17 & 1.27 & -4.03 & 2.63 \\
\hline $\begin{array}{l}\text { Promjena u udjelu stanovništva s fakul- } \\
\text { tetskom diplomom od 1991. do } 2011 . \\
\text { godine }\end{array}$ & 4.77 & 2.36 & 1.25 & 20.51 \\
\hline \multicolumn{5}{|l|}{ Naslijede ratova } \\
\hline $\begin{array}{l}\text { Broj invalida Domovinskog rata na ti- } \\
\text { suću stanovnika (Popis stanovništva iz } \\
\text { 2001. godine) }\end{array}$ & 10.03 & 7.96 & 0.15 & 40.37 \\
\hline $\begin{array}{l}\text { Broj invalida Drugog svjetskog rata na } \\
\text { tisuću stanovnika (Popis stanovništva iz } \\
\text { 2001. godine) }\end{array}$ & 3.77 & 2.41 & 0.73 & 14.01 \\
\hline
\end{tabular}

Napomena: 99 teritorijalnih jedinica (prilagođeno na temelju popisa stanovništva iz 1991. godine)

naslijeđe Jugoslavije i specifičan oblik socijalističkog razvoja koji je trajao u Jugoslaviji do kraja osamdesetih godina.

Druga grupa varijabli u Tablici 2 obuhvaća iste faktore koji su navedeni u prethodnom paragrafu, ali tako da se promatra njihova promjena od 1991. do 2011. godine. Ukoliko je aritmetička sredina oko nule, nije bilo promjene u tih dvadeset tranzicijskih godina. Ukoliko je ona negativna, dogodio se pad, a ako je pozitivna, dogodio se rast. Kao što se može vidjeti, najdramatičniji pad je bio u varijabli koja prati postotak srpskog stanovništva. Smanjenje udjela Srba u nekim sredinama doseže čak 50 posto, što je posljedica ratnih i poslijeratnih zbivanja. Udio industrijskih radnika je također uglavnom padao u najvećem broju teritorijalnih jedinica, što je posljedica propasti velikog dijela domaće industrije. Udio ateista uglavnom se malo smanjio, ali nije se dramatično mijenjao. Ova je mjera pogodna kao mjera za intenzitet kulturne i svjetonazorske promjene u zemlji. Udio fakultetski obrazovanog stanovništva umjereno je rastao, dok je rast udjela ekonomski uzdržavanog 
stanovništva možda najočitiji, oko 10 posto, ali negdje i preko 30 posto. To je jedan od pokazatelja ozbiljnog ekonomskog propadanja velikog broja lokalnih sredina u Hrvatskoj. Uzete zajedno, ove varijable operacionaliziraju burnu tranziciju kroz koju je prošla Hrvatska, njene demografske, ekonomske, obrazovne i svjetonazorske aspekte.

$\mathrm{Na}$ kraju, valja još operacionalizirati utjecaj ratova koji su se dogodili na ovom geografskom prostoru. Tablica 2 prikazuje deskriptivnu statistiku za dvije varijable. Riječ je o broju ratnih invalida Domovinskog rata i broju ratnih invalida Drugog svjetskog rata. Ovi su podaci u oba slučaja prikupljeni u popisu stanovništva 2001. godine. Podaci se, zbog relativno malih brojeva, prikazuju kao broj ratnih invalida na tisuću stanovnika. Razumije se, taj je broj zbog proteka vremena mnogo manji kada je riječ o Drugom svjetskom ratu. Riječ je o oko četvero ljudi na tisuću stanovnika, u usporedbi s Domovinskim ratom gdje prosječna teritorijalna jedinica ima oko desetero ratnih invalida na tisuću stanovnika. ${ }^{3} \mathrm{U}$ nekim se sredinama ta brojka penje do 40 ratnih invalida na tisuću stanovnika.

Pomoću ove dvije varijable moguće je mjeriti do koje je razine neka lokalna sredina obilježena iskustvom Domovinskog rata i Drugog svjetskog rata. Za očekivati je da su one sredine koje su više obilježene Drugim svjetskim ratom, te koje su više sudjelovale u partizanskim naporima, ujedno i pozitivnije vrednovale socijalističku Jugoslaviju te da danas u većoj mjeri podržavaju lijeve političke opcije. Suprotno bi važilo za desnicu. S druge pak strane, za očekivati bi bilo da su one sredine koje su više obilježene svojim sudjelovanjem u Domovinskom ratu danas sklonije u većoj mjeri podržavati desne političke opcije.

\section{Analiza}

Najvažniji multivarijantni modeli koji se koriste u ovom radu su prostorni regresijski modeli. Linearna regresijska analiza pretpostavila bi da su teritorijalne jedinice nasumično raspoređene u prostoru. Međutim, najčešće postoji odnos prostorne zavisnosti pa se jedinice koje imaju visoku vrijednost na jednoj varijabli grupiraju u prostoru pored drugih jedinica koje također imaju visoku vrijednost na toj varijabli (v. u: Anselin i Bera, 1998; Anselin, 2002; Anselin, 2010). U praktičnoj aplikaciji to znači da se u regresijske modele kao nezavisna varijabla može dodati varijabla koja prati vrijednost koju susjedne teritorijalne jedinice imaju na zavisnoj varijabli. $\mathrm{Na}$ taj se način kontrolira utjecaj geografskog grupiranja srodnih jedinica. Metodološki dodatak sadrži i linearne regresijske modele koji mogu biti dobar početni korak u analizi i linearne regresijske modele $u$ kojima se zavisna varijabla transformira $u$ prirodni logaritam izvorne vrijednosti, kao i logističke modele u kojim se zavisna varijabla transformira u dihotomnu.

Tablica $3 \mathrm{u}$ ovom radu predstavlja rezultate prostorne regresijske analize gdje se zavisne varijable formiraju na temelju izbornih rezultata 2011. godine. Tablica 4 čini to za izbore 2015. godine, Tablica 5 za izbore 2016. godine, a Tablica 6 za izbore 2020. godine. Kako bi se procijenila robusnost nalaza, potrebno je vidjeti koje

\footnotetext{
Broj ratnih invalida Drugog svjetskog rata je visoko koreliran s ukupnim brojem smrtno stradalih koji su živjeli u toj sredini. Ovi se podaci mogu pronaći na internetskoj stranici Miloša Popovića koja i inače sadrži odlične resurse za geografsku analizu (Popović, 2021). Autoritativni podaci za smrtno stradale u Domovinskom ratu još nisu dostupni, a nadležne institucije poput Hrvatskog memorijalno-dokumentacijskog centra Domovinskog rata još prikupljaju podatke. Kada ti i drugi podaci postanu dostupni, analiza će se moći proširiti.
} 
Tablica 3. Prostorni regresijski modeli postotka za različite političke opcije na parlamentarnim izborima 2011. godine

\begin{tabular}{lcc}
\hline & HDZ 2011. god. & SDP 2011. god. \\
\hline Naslijeđe Jugoslavije & & \\
\hline Udio uzdržavanog stanovništva 1991. godine & $0.536^{* *}$ & $-0.762^{* * *}$ \\
Udio industrijskih radnika u ukupnom stanovništvu & $(0.198)$ & $(0.228)$ \\
1991. godine & $-0.977^{* * *}$ & $0.655^{* *}$ \\
Udio Srba u ukupnom stanovništvu 1991. godine & $(0.174)$ & $(0.213)$ \\
Udio ateista i nevjernika u ukupnom stanovništvu & $-0.386^{* * *}$ & $0.348^{* * *}$ \\
1991. godine & $(0.054)$ & $(0.063)$ \\
Udio stanovništva s fakultetskom diplomom 1991. & $-1.907^{* * *}$ & $2.294^{* * *}$ \\
godine & $(0.253)$ & $(0.300)$ \\
Tranzicija od 1991. do 2011. godine & 0.522 & -0.051 \\
\hline Promjena u udjelu uzdržavanog stanovništva od 1991. & $(0.293)$ & $(0.339)$ \\
do 2011. godine & & $-0.514^{* *}$ \\
Promjena u udjelu industrijskih radnika od 1991. do & $(0.162)$ & $(0.186)$ \\
2011. godine & $-0.866^{* * *}$ & $0.825^{* *}$ \\
Promjena u udjelu Srba od 1991. do 2011. godine & $(0.212)$ & $(0.255)$ \\
Promjena u udjelu ateista i nevjernika od 1991. do & $-0.442^{* * *}$ & $0.463^{* * *}$ \\
2011. godine & $(0.084)$ & $(0.096)$ \\
Promjena u udjelu stanovništva s fakultetskom & $-2.209^{* * *}$ & $3.417^{* * *}$ \\
diplomom od 1991. do 2011. godine & $(0.473)$ & $(0.529)$ \\
\hline Naslijeđe ratova & -0.252 & 0.230 \\
\hline Broj invalida Domovinskog rata na tisuću stanovnika & $0.400^{* * *}$ & $(0.290)$ \\
(Popis stanovništva iz 2001. godine) & $(0.082)$ & $-0.374^{* * *}$ \\
Broj invalida Drugog svjetskog rata na tisuću & $1.185^{* * *}$ & $(0.093)$ \\
stanovnika (Popis stanovništva iz 2001.godine) & $(0.325)$ & -0.354 \\
\hline Prostorna varijabla & & $(0.374)$ \\
\hline Vrijednosti susjednih teritorijalnih jedinica na zavisnoj & $0.108^{* *}$ & \\
varijabli & $(0.039)$ & $0.075^{*}$ \\
Konstanta & 4.170 & $(0.033)$ \\
R na kvadrat & $(9.468)$ & 62.871 \\
\hline
\end{tabular}

Napomena: Koeficijenti i standardne pogreške u zagradama. Statistička značajnost $\mathrm{p}<0.05^{*}, \mathrm{p}<0.01^{\star *}$, $\mathrm{p}<0.001^{* * *}$

varijable imaju statistički značajne koeficijente $\mathrm{u}$ što većem broju modela (s istim predznakom).

Kao što se može vidjeti u tablicama 3, 4, 5 i 6, od varijabli iz prve grupe čimbenika, koji su operacionalizirali naslijeđe socijalističke Jugoslavije, može se izdvojiti jedna varijabla koja je bila statistički značajna u svim modelima: to je udio Srba koji je postajao u danoj teritorijalnoj jedinici 1991. godine. Što je taj postotak bio veći, to je rezultat koji HDZ (tj. desni blok) osvaja na recentnim izborima manji, a postotak koji osvaja SDP (tj. lijevi blok) veći. Prema tome, ukoliko je neka sredina "povijesno 
Tablica 4. Prostorni regresijski modeli postotka za različite političke opcije na parlamentarnim izborima 2015. godine

\begin{tabular}{|c|c|c|c|c|}
\hline & $\begin{array}{l}\text { HDZ } 2015 . \\
\text { god. }\end{array}$ & $\begin{array}{l}\text { SDP } 2015 . \\
\text { god. }\end{array}$ & $\begin{array}{c}\text { Desnica } \\
\text { 2015. god. } \\
\text { (HDZ i Most) }\end{array}$ & $\begin{array}{l}\text { Ljevica } \\
\text { 2015. god. } \\
\text { (SDP i IDS) }\end{array}$ \\
\hline \multicolumn{5}{|l|}{ Naslijeđe Jugoslavije } \\
\hline $\begin{array}{l}\text { Udio uzdržavanog stanovništva } 1991 . \\
\text { godine }\end{array}$ & $\begin{array}{c}0.754^{* * *} \\
(0.222)\end{array}$ & $\begin{array}{l}-0.411 \\
(0.288)\end{array}$ & $\begin{array}{l}0.837^{\star *} \\
(0.274)\end{array}$ & $\begin{array}{l}-0.506^{*} \\
(0.248)\end{array}$ \\
\hline $\begin{array}{l}\text { Udio industrijskih radnika u ukupnom } \\
\text { stanovništvu 1991. godine }\end{array}$ & $\begin{array}{l}-1.033^{* * *} \\
(0.196)\end{array}$ & $\begin{array}{l}0.566^{*} \\
(0.267)\end{array}$ & $\begin{array}{c}-1.403^{* * *} \\
(0.244)\end{array}$ & $\begin{array}{l}0.658^{* *} \\
(0.230)\end{array}$ \\
\hline $\begin{array}{l}\text { Udio Srba u ukupnom stanovništvu } 1991 . \\
\text { godine }\end{array}$ & $\begin{array}{l}-0.455^{* * *} \\
(0.061)\end{array}$ & $\begin{array}{c}0.303^{* * *} \\
(0.079)\end{array}$ & $\begin{array}{l}-0.616^{* * *} \\
(0.075)\end{array}$ & $\begin{array}{c}0.437^{* * *} \\
(0.068)\end{array}$ \\
\hline $\begin{array}{l}\text { Udio ateista i nevjernika u ukupnom } \\
\text { stanovništvu 1991. godine }\end{array}$ & $\begin{array}{l}-2.650^{* * *} \\
(0.284)\end{array}$ & $\begin{array}{c}0.099 \\
(0.372)\end{array}$ & $\begin{array}{l}-3.343^{* * *} \\
(0.351)\end{array}$ & $\begin{array}{l}2.922^{* * *} \\
(0.327)\end{array}$ \\
\hline $\begin{array}{l}\text { Udio stanovništva s fakultetskom } \\
\text { diplomom 1991. godine }\end{array}$ & $\begin{array}{c}0.646 \\
(0.331) \\
\end{array}$ & $\begin{array}{c}0.361 \\
(0.427)\end{array}$ & $\begin{array}{c}1.353^{* * *} \\
(0.410) \\
\end{array}$ & $\begin{array}{l}-0.042 \\
(0.364) \\
\end{array}$ \\
\hline \multicolumn{5}{|l|}{ Tranzicija od 1991. do 2011. godine } \\
\hline $\begin{array}{l}\text { Promjena u udjelu uzdržavanog } \\
\text { stanovništva od 1991. do 2011. godine }\end{array}$ & $\begin{array}{c}0.707^{* * *} \\
(0.181)\end{array}$ & $\begin{array}{l}-0.038 \\
(0.234)\end{array}$ & $\begin{array}{l}0.679^{* *} \\
(0.223)\end{array}$ & $\begin{array}{c}-0.412^{\star} \\
(0.202)\end{array}$ \\
\hline $\begin{array}{l}\text { Promjena u udjelu industrijskih radnika } \\
\text { od 1991. do 2011. godine }\end{array}$ & $\begin{array}{l}-1.111^{* * *} \\
(0.238)\end{array}$ & $\begin{array}{l}0.507 \\
(0.318)\end{array}$ & $\begin{array}{l}-1.612^{* * *} \\
(0.295)\end{array}$ & $\begin{array}{l}0.668^{*} \\
(0.275)\end{array}$ \\
\hline $\begin{array}{l}\text { Promjena u udjelu Srba od 1991. do } 2011 . \\
\text { godine }\end{array}$ & $\begin{array}{l}-0.588^{* * *} \\
(0.094)\end{array}$ & $\begin{array}{c}0.443^{* * *} \\
(0.122)\end{array}$ & $\begin{array}{l}-0.663^{* * *} \\
(0.116)\end{array}$ & $\begin{array}{c}0.501^{\star * *} \\
(0.104)\end{array}$ \\
\hline $\begin{array}{l}\text { Promjena u udjelu ateista i nevjernika od } \\
\text { 1991. do 2011. godine }\end{array}$ & $\begin{array}{l}-3.160^{* * *} \\
(0.530)\end{array}$ & $\begin{array}{c}0.069 \\
(0.664)\end{array}$ & $\begin{array}{l}-3.639^{* * *} \\
(0.651)\end{array}$ & $\begin{array}{l}4.449^{* * *} \\
(0.577)\end{array}$ \\
\hline $\begin{array}{l}\text { Promjena u udjelu stanovništva s } \\
\text { fakultetskom diplomom od 1991. do } \\
\text { 2011. godine }\end{array}$ & $\begin{array}{l}-0.434 \\
(0.283)\end{array}$ & $\begin{array}{c}0.392 \\
(0.366)\end{array}$ & $\begin{array}{c}0.106 \\
(0.350)\end{array}$ & $\begin{array}{c}0.460 \\
(0.313)\end{array}$ \\
\hline \multicolumn{5}{|l|}{ Naslijeđe ratova } \\
\hline $\begin{array}{l}\text { Broj invalida Domovinskog rata na tisuću } \\
\text { stanovnika (Popis stanovništva iz } 2001 . \\
\text { godine) }\end{array}$ & $\begin{array}{l}0.424^{\star * *} \\
(0.092)\end{array}$ & $\begin{array}{c}-0.530^{\star * *} \\
(0.118)\end{array}$ & $\begin{array}{l}0.472^{\star * *} \\
(0.114)\end{array}$ & $\begin{array}{c}-0.551^{\star * *} \\
(0.101)\end{array}$ \\
\hline $\begin{array}{l}\text { Broj invalida Drugog svjetskog rata na } \\
\text { tisuću stanovnika (Popis stanovništva iz } \\
\text { 2001. godine) }\end{array}$ & $\begin{array}{c}0.579 \\
(0.365)\end{array}$ & $\begin{array}{c}0.201 \\
(0.471)\end{array}$ & $\begin{array}{l}1.149^{*} \\
(0.451)\end{array}$ & $\begin{array}{l}-0.150 \\
(0.404)\end{array}$ \\
\hline \multicolumn{5}{|l|}{ Prostorna varijabla } \\
\hline $\begin{array}{l}\text { Vrijednosti susjednih teritorijalnih } \\
\text { jedinica na zavisnoj varijabli }\end{array}$ & $\begin{array}{l}0.082^{\star} \\
(0.033)\end{array}$ & $\begin{array}{l}-0.001 \\
(0.051)\end{array}$ & $\begin{array}{c}0.105^{* * \star} \\
(0.031)\end{array}$ & $\begin{array}{c}0.069 \\
(0.037)\end{array}$ \\
\hline Konstanta & $\begin{array}{c}9.224 \\
(10.618)\end{array}$ & $\begin{array}{l}44.510^{\star *} \\
(14.037)\end{array}$ & $\begin{array}{c}13.327 \\
(13.144)\end{array}$ & $\begin{array}{c}45.805^{* * *} \\
(12.044)\end{array}$ \\
\hline $\mathrm{N}$ & 99 & 99 & 99 & 99 \\
\hline R na kvadrat & 0.828 & 0.483 & 0.800 & 0.798 \\
\hline
\end{tabular}

Napomena: Koeficijenti i standardne pogreške u zagradama. Statistička značajnost $p<0.05^{*}, p<0.01^{* *}$, $\mathrm{p}<0.001^{* * *}$ 
Tablica 5. Prostorni regresijski modeli postotka za različite političke opcije na parlamentarnim izborima 2016. godine

\begin{tabular}{|c|c|c|c|c|}
\hline & $\begin{array}{l}\text { HDZ } 2016 . \\
\text { god. }\end{array}$ & $\begin{array}{l}\text { SDP } 2016 . \\
\text { god. }\end{array}$ & $\begin{array}{c}\text { Desnica } \\
\text { 2016. god. } \\
\text { (HDZ i Most) }\end{array}$ & $\begin{array}{c}\text { Ljevica } \\
\text { 2016. god. } \\
\text { (SDP i IDS) }\end{array}$ \\
\hline \multicolumn{5}{|l|}{ Naslijeđe Jugoslavije } \\
\hline $\begin{array}{l}\text { Udio uzdržavanog stanovništva } 1991 . \\
\text { godine }\end{array}$ & $\begin{array}{l}0.658^{\star *} \\
(0.214)\end{array}$ & $\begin{array}{l}-0.472 \\
(0.292)\end{array}$ & $\begin{array}{l}0.657^{*} \\
(0.263)\end{array}$ & $\begin{array}{l}-0.587^{*} \\
(0.244)\end{array}$ \\
\hline $\begin{array}{l}\text { Udio industrijskih radnika u ukupnom } \\
\text { stanovništvu 1991. godine }\end{array}$ & $\begin{array}{l}-1.178^{* * *} \\
(0.190)\end{array}$ & $\begin{array}{c}0.465 \\
(0.273)\end{array}$ & $\begin{array}{l}-1.598^{* * *} \\
(0.233)\end{array}$ & $\begin{array}{l}0.656^{* *} \\
(0.228)\end{array}$ \\
\hline $\begin{array}{l}\text { Udio Srba u ukupnom stanovništvu } 1991 . \\
\text { godine }\end{array}$ & $\begin{array}{l}-0.394^{* * *} \\
(0.059)\end{array}$ & $\begin{array}{l}0.192^{\star} \\
(0.080)\end{array}$ & $\begin{array}{l}-0.515^{* * *} \\
(0.072)\end{array}$ & $\begin{array}{c}0.345^{* * *} \\
(0.067)\end{array}$ \\
\hline $\begin{array}{l}\text { Udio ateista i nevjernika u ukupnom } \\
\text { stanovništvu 1991. godine }\end{array}$ & $\begin{array}{l}-2.288^{* * *} \\
(0.274)\end{array}$ & $\begin{array}{l}-0.200 \\
(0.377)\end{array}$ & $\begin{array}{c}-3.027^{* * *} \\
(0.336)\end{array}$ & $\begin{array}{c}2.764^{* * *} \\
(0.323)\end{array}$ \\
\hline $\begin{array}{l}\text { Udio stanovništva s fakultetskom } \\
\text { diplomom 1991. godine }\end{array}$ & $\begin{array}{c}0.456 \\
(0.321) \\
\end{array}$ & $\begin{array}{c}0.360 \\
(0.434) \\
\end{array}$ & $\begin{array}{l}1.072^{* *} \\
(0.393) \\
\end{array}$ & $\begin{array}{l}-0.121 \\
(0.359) \\
\end{array}$ \\
\hline \multicolumn{5}{|l|}{ Tranzicija od 1991. do 2011. godine } \\
\hline $\begin{array}{l}\text { Promjena u udjelu uzdržavanog } \\
\text { stanovništva od 1991. do 2011. godine }\end{array}$ & $\begin{array}{c}0.624^{* \star *} \\
(0.175)\end{array}$ & $\begin{array}{l}-0.035 \\
(0.238)\end{array}$ & $\begin{array}{l}0.526^{*} \\
(0.214)\end{array}$ & $\begin{array}{c}-0.422^{*} \\
(0.200)\end{array}$ \\
\hline $\begin{array}{l}\text { Promjena u udjelu industrijskih radnika } \\
\text { od 1991. do 2011. godine }\end{array}$ & $\begin{array}{l}-1.269^{* * *} \\
(0.230)\end{array}$ & $\begin{array}{c}0.478 \\
(0.324)\end{array}$ & $\begin{array}{l}-1.809^{* * *} \\
(0.282)\end{array}$ & $\begin{array}{l}0.723^{* *} \\
(0.272)\end{array}$ \\
\hline $\begin{array}{l}\text { Promjena u udjelu Srba od 1991. do } 2011 . \\
\text { godine }\end{array}$ & $\begin{array}{l}-0.480^{* * *} \\
(0.091)\end{array}$ & $\begin{array}{l}0.290^{*} \\
(0.123)\end{array}$ & $\begin{array}{l}-0.487^{* * *} \\
(0.111)\end{array}$ & $\begin{array}{c}0.349^{* * *} \\
(0.103)\end{array}$ \\
\hline $\begin{array}{l}\text { Promjena u udjelu ateista i nevjernika od } \\
\text { 1991. do 2011. godine }\end{array}$ & $\begin{array}{l}-2.726^{* * *} \\
(0.510)\end{array}$ & $\begin{array}{l}-0.290 \\
(0.674)\end{array}$ & $\begin{array}{l}-3.533^{* * *} \\
(0.624)\end{array}$ & $\begin{array}{l}4.295^{* * *} \\
(0.569)\end{array}$ \\
\hline $\begin{array}{l}\text { Promjena u udjelu stanovništva s } \\
\text { fakultetskom diplomom od 1991. do } 2011 . \\
\text { godine }\end{array}$ & $\begin{array}{l}-0.193 \\
(0.273)\end{array}$ & $\begin{array}{c}0.236 \\
(0.372)\end{array}$ & $\begin{array}{l}-0.088 \\
(0.335)\end{array}$ & $\begin{array}{c}0.286 \\
(0.309)\end{array}$ \\
\hline \multicolumn{5}{|l|}{ Naslijeđe ratova } \\
\hline $\begin{array}{l}\text { Broj invalida Domovinskog rata na tisuću } \\
\text { stanovnika (Popis stanovništva iz } 2001 . \\
\text { godine) }\end{array}$ & $\begin{array}{c}0.491^{\star * *} \\
(0.089)\end{array}$ & $\begin{array}{c}-0.621^{\star * *} \\
(0.120)\end{array}$ & $\begin{array}{c}0.542^{\star * *} \\
(0.109)\end{array}$ & $\begin{array}{c}-0.651^{* * *} \\
(0.100)\end{array}$ \\
\hline $\begin{array}{l}\text { Broj invalida Drugog svjetskog rata na } \\
\text { tisuću stanovnika (Popis stanovništva iz } \\
\text { 2001. godine) }\end{array}$ & $\begin{array}{l}0.751^{*} \\
(0.353)\end{array}$ & $\begin{array}{l}-0.195 \\
(0.480)\end{array}$ & $\begin{array}{l}1.432^{\star * *} \\
(0.432)\end{array}$ & $\begin{array}{l}-0.666 \\
(0.399)\end{array}$ \\
\hline \multicolumn{5}{|l|}{ Prostorna varijabla } \\
\hline $\begin{array}{l}\text { Vrijednosti susjednih teritorijalnih } \\
\text { jedinica na zavisnoj varijabli }\end{array}$ & $\begin{array}{l}0.073^{\star} \\
(0.031)\end{array}$ & $\begin{array}{c}0.092 \\
(0.051)\end{array}$ & $\begin{array}{c}0.112^{\star * *} \\
(0.031)\end{array}$ & $\begin{array}{l}0.117^{\star *} \\
(0.036)\end{array}$ \\
\hline Konstanta & $\begin{array}{c}13.144 \\
(10.273)\end{array}$ & $\begin{array}{l}49.034^{* * *} \\
(14.282)\end{array}$ & $\begin{array}{c}20.679 \\
(12.593)\end{array}$ & $\begin{array}{c}52.164^{* * *} \\
(11.897)\end{array}$ \\
\hline $\mathrm{N}$ & 99 & 99 & 99 & 99 \\
\hline R na kvadrat & 0.826 & 0.511 & 0.816 & 0.820 \\
\hline
\end{tabular}

Napomena: Koeficijenti i standardne pogreške u zagradama. Statistička značajnost $\mathrm{p}<0.05^{\star}, \mathrm{p}<0.01^{\star *}$, $\mathrm{p}<0.001^{* * *}$ 
Tablica 6. Prostorni regresijski modeli postotka za različite političke opcije na parlamentarnim izborima 2020. godine

\begin{tabular}{|c|c|c|c|c|}
\hline & $\begin{array}{l}\text { HDZ } 2020 . \\
\text { god. }\end{array}$ & $\begin{array}{l}\text { SDP } 2020 . \\
\text { god. }\end{array}$ & $\begin{array}{l}\text { Desnica } \\
\text { 2020. god. } \\
\text { (HDZ, Most } \\
\text { i DP) } \\
\end{array}$ & $\begin{array}{c}\text { Ljevica } 2020 . \\
\text { god. (SDP i } \\
\text { Možemo!) }\end{array}$ \\
\hline \multicolumn{5}{|l|}{ Naslijeđe Jugoslavije } \\
\hline $\begin{array}{l}\text { Udio uzdržavanog stanovništva } 1991 . \\
\text { godine }\end{array}$ & $\begin{array}{c}0.785^{\star * *} \\
(0.202)\end{array}$ & $\begin{array}{l}-0.324 \\
(0.245)\end{array}$ & $\begin{array}{l}0.855^{\star *} \\
(0.293)\end{array}$ & $\begin{array}{l}-0.464 \\
(0.256)\end{array}$ \\
\hline $\begin{array}{l}\text { Udio industrijskih radnika u ukupnom } \\
\text { stanovništvu 1991. godine }\end{array}$ & $\begin{array}{l}-0.745^{* * *} \\
(0.181)\end{array}$ & $\begin{array}{l}0.515^{*} \\
(0.227)\end{array}$ & $\begin{array}{l}-1.257^{* * *} \\
(0.262)\end{array}$ & $\begin{array}{l}0.483^{*} \\
(0.236)\end{array}$ \\
\hline $\begin{array}{l}\text { Udio Srba u ukupnom stanovništvu } 1991 . \\
\text { godine }\end{array}$ & $\begin{array}{l}-0.272^{* * *} \\
(0.056)\end{array}$ & $\begin{array}{c}0.249^{* * *} \\
(0.067)\end{array}$ & $\begin{array}{l}-0.301^{* * *} \\
(0.081)\end{array}$ & $\begin{array}{c}0.286^{* * *} \\
(0.070)\end{array}$ \\
\hline $\begin{array}{l}\text { Udio ateista i nevjernika u ukupnom } \\
\text { stanovništvu 1991. godine }\end{array}$ & $\begin{array}{l}-2.449^{* * *} \\
(0.259)\end{array}$ & $\begin{array}{c}2.669^{* * *} \\
(0.325)\end{array}$ & $\begin{array}{c}-3.486^{* * *} \\
(0.376)\end{array}$ & $\begin{array}{c}3.154^{* * *} \\
(0.341)\end{array}$ \\
\hline $\begin{array}{l}\text { Udio stanovništva s fakultetskom } \\
\text { diplomom 1991. godine }\end{array}$ & $\begin{array}{l}0.653^{*} \\
(0.304) \\
\end{array}$ & $\begin{array}{l}-0.217 \\
(0.359) \\
\end{array}$ & $\begin{array}{l}1.047^{*} \\
(0.443) \\
\end{array}$ & $\begin{array}{l}-0.317 \\
(0.376)\end{array}$ \\
\hline \multicolumn{5}{|l|}{ Tranzicija od 1991. do 2011. godine } \\
\hline $\begin{array}{l}\text { Promjena u udjelu uzdržavanog } \\
\text { stanovništva od 1991. do 2011. godine }\end{array}$ & $\begin{array}{c}0.648^{\star * *} \\
(0.165)\end{array}$ & $\begin{array}{l}-0.277 \\
(0.200)\end{array}$ & $\begin{array}{l}0.579^{*} \\
(0.239)\end{array}$ & $\begin{array}{l}-0.384 \\
(0.209)\end{array}$ \\
\hline $\begin{array}{l}\text { Promjena u udjelu industrijskih radnika } \\
\text { od 1991. do 2011. godine }\end{array}$ & $\begin{array}{c}-0.570^{* *} \\
(0.218)\end{array}$ & $\begin{array}{l}0.631^{*} \\
(0.272)\end{array}$ & $\begin{array}{c}-1.309^{* * *} \\
(0.316)\end{array}$ & $\begin{array}{l}0.627^{*} \\
(0.284)\end{array}$ \\
\hline $\begin{array}{l}\text { Promjena u udjelu Srba od 1991. do } \\
\text { 2011. godine }\end{array}$ & $\begin{array}{c}-0.377^{\star * *} \\
(0.086)\end{array}$ & $\begin{array}{l}0.286^{* *} \\
(0.103)\end{array}$ & $\begin{array}{c}-0.378^{\star *} \\
(0.124)\end{array}$ & $\begin{array}{l}0.274^{*} \\
(0.108)\end{array}$ \\
\hline $\begin{array}{l}\text { Promjena u udjelu ateista i nevjernika od } \\
\text { 1991. do 2011. godine }\end{array}$ & $\begin{array}{l}-3.012^{* * *} \\
(0.481)\end{array}$ & $\begin{array}{c}3.719^{* * *} \\
(0.573)\end{array}$ & $\begin{array}{l}-4.729^{* * *} \\
(0.696)\end{array}$ & $\begin{array}{l}4.152^{* * *} \\
(0.600)\end{array}$ \\
\hline $\begin{array}{l}\text { Promjena u udjelu stanovništva s } \\
\text { fakultetskom diplomom od 1991. do } \\
\text { 2011. godine }\end{array}$ & $\begin{array}{l}-0.348 \\
(0.259)\end{array}$ & $\begin{array}{c}0.009 \\
(0.310)\end{array}$ & $\begin{array}{l}-0.367 \\
(0.375)\end{array}$ & $\begin{array}{l}0.652^{*} \\
(0.323)\end{array}$ \\
\hline \multicolumn{5}{|l|}{ Naslijeđe ratova } \\
\hline $\begin{array}{l}\text { Broj invalida Domovinskog rata na tisuću } \\
\text { stanovnika (Popis stanovništva iz } 2001 . \\
\text { godine) }\end{array}$ & $\begin{array}{c}0.317^{* * *} \\
(0.084)\end{array}$ & $\begin{array}{l}-0.395^{* * *} \\
(0.100)\end{array}$ & $\begin{array}{c}0.457^{\star * *} \\
(0.122)\end{array}$ & $\begin{array}{c}-0.419^{* * *} \\
(0.104)\end{array}$ \\
\hline $\begin{array}{l}\text { Broj invalida Drugog svjetskog rata na } \\
\text { tisuću stanovnika (Popis stanovništva iz } \\
\text { 2001. godine) }\end{array}$ & $\begin{array}{c}0.543 \\
(0.335)\end{array}$ & $\begin{array}{l}-0.168 \\
(0.400)\end{array}$ & $\begin{array}{c}0.172 \\
(0.485)\end{array}$ & $\begin{array}{l}-0.380 \\
(0.417)\end{array}$ \\
\hline \multicolumn{5}{|l|}{ Prostorna varijabla } \\
\hline $\begin{array}{l}\text { Vrijednosti susjednih teritorijalnih } \\
\text { jedinica na zavisnoj varijabli }\end{array}$ & $\begin{array}{c}0.055 \\
(0.029)\end{array}$ & $\begin{array}{l}0.137^{* *} \\
(0.046)\end{array}$ & $\begin{array}{l}0.081^{* *} \\
(0.030)\end{array}$ & $\begin{array}{l}0.133^{\star *} \\
(0.042)\end{array}$ \\
\hline Konstanta & $\begin{array}{l}10.343 \\
(9.732)\end{array}$ & $\begin{array}{l}32.356^{* *} \\
(11.903)\end{array}$ & $\begin{array}{c}27.438 \\
(14.085)\end{array}$ & $\begin{array}{l}38.037^{* *} \\
(12.418)\end{array}$ \\
\hline $\mathrm{N}$ & 99 & 99 & 99 & 99 \\
\hline R na kvadrat & 0.812 & 0.734 & 0.794 & 0.774 \\
\hline
\end{tabular}

Napomena: Koeficijenti i standardne pogreške u zagradama. Statistička značajnost $\mathrm{p}<0.05^{*}, \mathrm{p}<0.01^{* *}$, $\mathrm{p}<0.001^{* * *}$ 
srpska", to smanjuje vjerojatnost da će se okrenuti desnici, a povećava vjerojatnost da će se okrenuti ljevici.

Iduće varijable nisu bile statistički značajne u svim modelima, ali jesu u većini njih. Riječ je o udjelu ateista koji je postojao u danoj teritorijalnoj jedinici 1991. godine. Što je taj postotak bio veći, to je izborni rezultat HDZ-a (i desnog bloka) u recentnim godinama lošiji. S druge strane, što je taj postotak bio veći to je recentni izborni rezultat SDP-a (i lijevog bloka) bio bolji. Prema tome, ako neka sredina ima "tradiciju" veće sekularnosti, ona ujedno ima i manju vjerojatnost da se okrene desnim političkim opcijama. Isto vrijedi za udio industrijskih radnika koji je postojao 1991. godine, dakle prije početka tranzicije i privatizacije. Ova je varijabla pozitivno povezana s postotkom koji osvaja SDP (i lijevi blok), a negativno povezana s postotkom koji osvaja HDZ (i desni blok). Prema tome, tradicija veće industrijaliziranosti, tj. prisutnosti značajnije industrijske radničke klase na početku tranzicije, pojačava vjerojatnost da se neka sredina okrene lijevim opcijama, a smanjuje vjerojatnost da se okrene desnici.

Najzad, udio uzdržavanog stanovništva iz 1991. godine se također često pojavljuje kao statistički značajan prediktor. Pozitivno je povezan s izbornim uspjehom HDZ-a (i desnog bloka), a negativno je povezan s izbornim uspjehom SDP-a (i lijevog bloka) na nedavnim izborima. Prema tome, one sredine koje su 1991. godine imale viši postotak uzdržavanog stanovništva - tj. one sredine koje imaju "povijest" veće ekonomske pasivnosti i koje se u socijalističkoj Jugoslaviji nisu uspjele razviti - pokazuju veću sklonost tome da se okrenu desnim opcijama, a manju sklonost da se okrenu lijevim opcijama.

Slični se rezultati ponavljaju i kada je riječ o varijablama koje prate učinak tranzicije, tj. u varijablama koje prate promjenu od popisa iz 1991. godine do popisa iz 2011. godine. Najkonzistentniji je prediktor promjena u udjelu srpskog stanovništva. Dakle, SDP (i lijevi blok) je ostvario veći postotak glasova ondje gdje je porast u udjelu Srba bio veći, dok za HDZ (i desni blok) vrijedi obrnuto. Međutim, s obzirom na to da je gotovo svuda postotak Srba opao, negdje i veoma dramatično, točnija bi interpretacija bila ta da ovakav rezultat znači da SDP i lijevi blok tim lošije prolaze na recentnim izborima kako je pad u postotku Srba bio veći. Kod desnih opcija vrijedi obrnuta logika, njima je veći pad u postotku Srba povezan s porastom postotka glasova na nedavnim izborima.

Još tri varijable iz ove grupe faktora se često pojavljuju kao statistički značajne u prostornim modelima. To su promjena u udjelu ateista, promjena u udjelu industrijskih radnika i promjena u udjelu uzdržavanog stanovništva. Kao što se vidi, što je porast u udjelu ateista bio veći, to je postotak za SDP (i lijevi blok) na nedavnim izborima veći. Za HDZ (i desni blok) vrijedi obrnuto. Isto je i s promjenom u udjelu industrijskih radnika. Ona je pozitivno povezana s postotkom kojeg osvaja SDP (i lijevi blok), a negativno je povezana s postotkom kojeg osvaja HDZ. Prema tome, dezindustrijalizacija povećava postotak kojeg osvaja desnica. Drugačije je, pak, s promjenom u udjelu uzdržavanog stanovništva: porast u toj varijabli od 1991. do 2011. godine povezan je s boljim rezultatom HDZ-a (i desnog bloka) na nedavnim izborima, dok za SDP (i lijevi blok) vrijedi obrnuto.

Prije nego što diskusija pređe na varijable koje prate naslijeđe ratova, treba napomenuti da se varijabla koja prati udio fakultetski obrazovanog stanovništva nije pokazala kao robustni prediktor u modelima koji su prikazani u tablicama 3 do 6 , niti kao razina koja je postojala na lokalnoj razini 1991. godini niti kao postotna promjena od 1991. do 2011. godine. 
Treća grupa varijabli operacionalizira učinak ratnog naslijeđa. Kada je riječ o varijabli koja prati broj ratnih invalida Domovinskog rata, može se jasno vidjeti da je ta varijabla pozitivno povezana s izbornim uspjehom HDZ-a (i desnog bloka), a negativno povezana s izbornim uspjehom SDP-a (i lijevog bloka). Prema tome, ondje gdje ratnih invalida Domovinskog rata ima više, desnica osvaja veći postotak glasova, dok ljevica osvaja manji postotak glasova. To je možda i najjasniji nalaz iz čitave ove analize. ${ }^{4}$ Kada je riječ o broju ratnih invalida Drugog svjetskog rata ne može se zaključiti da bilo kakav efekt postoji. U nekoliko je modela ta varijabla čak pozitivno povezana s postotkom glasova za desnicu, ali nalaz nije robustan pa je iz opreza bolje zaključiti kako nikakve čvrste veze nema. Prema tome, čini se da je ratno naslijeđe učinkovito samo kada je riječ o Domovinskom ratu, ali ne i kada je riječ o Drugom svjetskom ratu. ${ }^{5}$

Treba još napomenuti da se koeficijent varijable za prostornu zavisnost konstantno pojavljuje kao statistički značajan, što je bilo i očekivano, s obzirom na geografski raspored koji se vidi na kartama 1 i 2 . Metodološki dodatak širi ovu analizu na linearne regresijske modele i na linearne regresijske modele sa log-transformiranom zavisnom varijablom, a nalazi koji proizlaze iz te analize u velikoj se mjeri podudaraju s analizom koja je ovdje prikazana.

Kada je riječ o veličini efekta, a ne samo o statističkoj značajnosti, iz prethodne se analize može donijeti nekoliko kratkih zaključaka. Može se početi najprije s varijablama koje su najčešće bile statistički značajne. Kada je riječ o varijabli koja prati broj ratnih invalida Domovinskog rata, može se reći da za zamišljeni porast od jednog ratnog invalida na tisuću stanovnika, postotak glasova koji osvaja desnica raste za otprilike 0.3 do otprilike 0.5 , a postotak koji osvaja ljevica pada za otprilike 0.4 do 0.6. Osim tog nalaza, valjalo bi još izdvojiti učinak postotne promjene u postoku srpskog stanovništva. Kako se ona (u zamišljenoj komparaciji unutar regresijske analize) poveća za jedan postotni poen, tako postotak koji osvaja desnica pada za otprilike 0.4 do 0.5 , a postotak koji osvaja ljevica raste za 0.3 do 0.6 . Ponovo, s obzirom na to da je postotak Srba uglavnom padao za najveći broj teritorijalnih jedinica, bilo bi ispravnije reći slijedeće: kako se se zamisli ili dogodi pad u udjelu Srba od 1 posto, tako na nedavnim izborima postotak koji osvaja desnica raste za otprilike 0.4 do 0.5 posto, a postotak kojeg osvaja ljevica pada za 0.3 do 0.6 posto.

Neki drugi koeficijenti su čak i viši od toga, kao što se može vidjeti u tablicama 3 do 6. Najviši je koeficijent za varijablu koja prati udio ateista 1991. godine i za postotnu promjenu u udjelu ateista od 1991. do 2011. godine. To je vjerojatno, barem djelomice, rezultat niskog postotka ove populacije koja postoji u najvećem broju teritorijalnih jedinica. Ali valja naglasiti kako bi (u kontrafaktičnom svijetu regresijske analize), potencijalne koristi koje ljevica ima od većeg broja ateista mogle biti izrazito velike. Ako se pogled zadrži samo na postotnoj promjeni koja se dogodila od 1991. do 2011. godine, može se vidjeti da postotak koji osvaja ljevica na nedavnim izborima raste za 3 do 4 posto kako se dogodi (zamišljeni) porast od 1 posto u udjelu ateista. Dok se za desnicu događa korespondirajući pad od visokih 2 do 5 posto.

4 Također, ovo je jedini nalaz kojeg potvrđuju i dva modela koja primjenjuju logističku regresiju u metodološkom dodatku. Prema tome, njega treba tretirati kao najrobusniji nalaz, a ostale koji se ovdje navode kao manje robusne od njega.

5 Prije spomenuta varijabla koja prati ukupni broj smrtno stradalih u Drugom svjetskom ratu također nije rezultirala statistički značajnim rezultatima. 


\section{Rasprava}

Ovaj se rad bavio analizom jedne važne činjenice hrvatske politike: utvrđenosti političkih identiteta u geografskom prostoru. Naime, podjela na "dvije Hrvatske" ne postoji samo u simboličkom prostoru kojeg mogu mapirati ankete pojedinačnih ispitanika, nego i u stvarnom geografskom prostoru. "Crvena" Hrvatska obično glasa za stranke i opcije s lijeve strane političkog spektra, a "crna" za stranke i kandidate desnice.

Mogu li se locirati neki dugoročni faktori koji utječu na taj geografski raspored? Ova je analiza počela s tri grupe faktora. Prvo, mogu se uzeti strukturni faktori koji su naslijeđeni iz socijalističke Jugoslavije, dakle određeni indikatori dosegnute razine razvoja na lokalnoj razini. Drugo, mogu se uzeti faktori koji su proizašli iz burne ekonomske, demografske i svjetonazorske tranzicije koja se dogodila od raspada socijalističke Jugoslavije do danas. I treće, valja uzeti u obzir i faktore koji su povezani $s$ naslijeđem ratnih zbivanja na ovim prostorima, posebice Drugog svjetskog rata i Domovinskog rata. Osnovna zavisna varijabla ovog rada - lokalni politički identiteti - operacionalizirana je postotkom kojeg ostvaruju dvije velike političke stranke desnog i lijevog centra, kako zasebno tako i u kombinaciji sa srodnim strankama lijevog i desnog bloka, za sve parlamentarne izbore u proteklom desetljeću.

Što pokazuju nalazi? Najprije, neki faktori koji su povezani s naslijeđem Jugoslavije pokazali su se kao relevantni prediktori danih zavisnih varijabli. Najprije, tu je udio srpskog stanovništva koji je postojao na lokalnoj razini 1991. godine koji je pozitivno povezan s lijevim (crvenim), a negativno povezan s desnim (crnim) opcijama. Prema tome, ako je neka sredina u većoj mjeri "povijesno" srpska, ona se i u nedavnim izborima u većoj mjeri okreće ljevici. Isto vrijedi za udio ateista koji je postojao na lokalnoj razini 1991. godine. Tu je, dakle, riječ o postignutoj razini sekularizacije. Ona je, doduše, svuda bila relativno niska, ali je ipak pozitivno povezana s lijevim (crvenim) opcijama, a negativno s desnim (crnim) opcijama. Slično vrijedi za udio industrijskih radnika koji je postojao u trenutku prije nego što je započela tranzicija. Taj je udio pozitivno povezan s postotkom koji u posljednjim godinama osvaja ljevica. Suprotno vrijedi za udio ekonomski uzdržavanog stanovništva. Dakle, ekonomska pasivnost koja je postojala 1991. godine i dan-danas je pozitivno povezana s desnim (crnim) lokalnim identitetima. Riječ je dakle o neuspjehu tih lokalnih sredina da se razviju u četiri desetljeća socijalističkog razvoja (a vjerojatno i ranije) te se takve sredine i u recentnim izborima u većoj mjeri okreću desnici.

Slični se nalazi mogu pronaći i kada se takve varijable promatraju kao promjena od 1991. do 2011. godine. Riječ je, dakle, o efektu tranzicije. Strmi pad u udjelu Srba na lokalnoj sredini negativno se odražava na postotak koji u toj sredini osvajaju lijeve (crvene) opcije, a pozitivno na postotak koji osvajaju desne (crne) opcije. Prema tome, etnička homogenizacija koja je postignuta tijekom i nakon Domovinskog rata uvelike je odgovarala desnici. Manje dramatičan, ali ipak značajan pad se dogodio i $s$ udjelom industrijskih radnika, te je taj pad opet pogodio lijeve (crvene) političke opije, dok je pogodovao desnim (crnim) opcijama. Ekonomska tranzicija je oslabila radničku klasu, što je pak osnažilo desne političke opcije. Udio ateista se nije tako drastično mijenjao, ali ipak postoji ista veza kao i kod gore spomenutih varijabli: rast broja ateista je povezan s rastom podrške za lijeve opcije, dok za desnicu vrijedu obrnuto. Suprotno je kod varijable koja prati promjenu u udjelu uzdržavanog stanovništva. Kako raste udio ekonomski pasivnih, desne (crne) političke opcije profitiraju, a lijeve (crvene) gube. Ekonomsko propadanje se, dakle, veže uz bolji 
rezultat desnice. Prema tome, i dugoročna "tradicija" ekonomske zaostalosti kao i daljnje ekonomsko propadanje u recentnoj povijesti povezano je s jačanjem desnih političkih identiteta.

Ova analiza sugerira nekoliko mogućih zaključaka. Desnica uspijeva poentirati na više trendova nego ljevica. Dezindustrijalizacija, koja je ovdje mjerena padom u udjelu industrijskih radnika, pogoduje desnici, kao i srodan proces ekonomskog siromašenja i ekonomske pasivizacije koji je ovdje mjeren rastom uzdržavanog stanovništva. Osim toga, etnička homogenizacija zemlje koja se dogodila s velikim poslijeratnim smanjenjem srpskog stanovništva također je nešto od čega političke koristi izvlači desnica. Načelno, ljevica bi mogla te gubitke nadoknaditi ako bi sile koje guraju u suprotnom pravcu bile jače, ali čini se da to nije slučaj. Prije svega, ljevica može značajno povećati svoju bazu ondje gdje se događa rast sekularnog (nereligioznog) stanovništva. Naravno, drugo je pitanje kako se može postići značajniji rast nereligioznosti, a ova analiza ne može dati odgovore na to pitanje. Čini se da širenje obrazovanosti nema isti efekt kao širenje ateizma, barem nije imalo $u$ analizi koja je provedena u ovom radu. Ukratko, desni (crni) politički identiteti ukorjenjuju se ondje gdje postoji značajnija ekonomska pasivnost, etnička homogenost, slabost industrije te jača religioznost. Za ljevicu vrijedi obrnuto.

Na kraju, treći skup faktora koji se analizirao u ovom radu veže se uz naslijeđe ratnih zbivanja na ovom prostoru. Kada je riječ o naslijeđu Drugog svjetskog rata, čini se da je veza tog faktora i današnjih političkih identiteta lokalnih sredina uglavnom veoma slaba. Premda se ne može decidirano tvrditi koliko dugo jedna sredina može "pamtiti", čini se da je 75 godina (koliko je proteklo od Drugog svjetskog rata) ipak predugo. Ranije su analize naglašavale značaj "duge ruke" Drugog svjetskog rata, ali ova analiza nije pronašla dokaze za tu tezu. Osim toga, treba reći da ne postoji ni neki trend opadanja kroz vrijeme, od izbora 2011. godine do izbora 2020. godine.

Međutim, naslijeđe Domovinskog rata je itekako stvarno. Političke koristi od njega ima desnica, a štete ljevica. Premda se ne može sasvim jasno ustvrditi koliko dugo traje povezanost tog tipa, čini se da može biti barem 25 godina (koliko je proteklo od Domovinskog rata). Vjerojatno je to povezano s prirodnim procesom starenja onih koji su tu epizodu osobno proživjeli. Ukoliko je tako, može se očekivati da će ovdje utvrđena veza slabjeti kako sami sudionici Domovinskog rata budu starili. Naravno, učinak Domovinskog rata može, načelno gledajući, nadživjeti njegove sudionike, kroz politiku ritualiziranog prisjećanja. Dapače, desni politički akteri će vjerojatno morati posegnuti upravo za takvim taktikama s obzirom na to da se druge strukturne sile koje im pogoduju - kao što su ovdje podcrtani procesi dezindustrijalizacije, ekonomske pasivizacije i etničke homogenizacije - ipak ne mogu eksplicitno promicati u redovnim političkim okolnostima. 


\section{Literatura}

Anselin, L., i Bera, A. (1998). Spatial Dependence in Linear Regression Models With An Introduction to Spatial Econometrics. U: A. Ullah i D. Giles (ur.), Handbook of Applied Economic Statistics (str. 237-278). New York: Marcel Dekker.

Anselin, L. (2002). Under the Hood: Issues in the Specification and Interpretation of Spatial Regression Models. Agricultural Economics, 27, 247-267. https://doi.org/ 10.1111/j.1574-0862.2002.tb00120.x

Anselin, L. (2010). Thirty Years of Spatial Econometrics. Papers in Regional Science, 89(1), 3-25. https://doi.org/10.1111/j.1435-5957.2010.00279.x

Bagić, D. (2007). Društveni rascjepi i stranačke preferencije na izborima za Hrvatski Sabor 2003. godine. Politička misao, 44(4), 93-115.

Balcells, L. (2011). The Consequences of Victimization on Political Identities: Evidence from Spain. Politics and Society, 4(3), 311-347. https://doi.org/ $10.1177 \% 2$ F0032329211424721

Costalli, S., i Ruggeri, A. (2019). The Long-Term Electoral Legacies of Civil War in Young Democracies: Italy, 1946-1948. Comparative Political Studies, 52(6), 927961. https://doi.org/10.1177/0010414018784057

Čular, G. (2004). Stranačka identifikacija i potpora demokraciji u Hrvatskoj. Politička misao, 40(4), 3-24.

Dolenec, D. (2012). The Absent Socioeconomic Cleavage in Croatia: A Failure of Representative Democracy? Politička misao, 49(5), 69-88.

DIP (Državno izborno povjerenstvo). (2021). Arhiva izbornih rezultata. https:// www.izbori.hr/arhiva-izbora/\#/app/home

Ford, R., i Goodwin, M. (2014). Revolt on the Right: Explaining Support for the Radical Right in Britain. London: Routledge.

Furlong, J. (2019). The Changing Electoral Geography of England and Wales: Varieties of 'Left-Behindedness'. Political Geography, 75. https://doi.org/10.1016/j. polgeo.2019.102061

Glaurdić, J., i Vuković, V. (2015). Prosperity and Peace: Economic Interests and War Legacy in Croatia's EU Referendum Vote. European Union Politics, 16(4), 577-600. https://doi.org/10.1177\%2F1465116515580179

Glaurdić, J., i Vuković, V. (2016a). Proxy Politics, Economic Protest, or Traditionalist Backlash: Croatia's Referendum on the Constitutional Definition of Marriage. Europe-Asia Studies, 68(5), 803-825. https://doi.org/10.1080/09668136.2016.118 6610

Glaurdić, J. i Vuković, V. (2016b). Voting after War: Legacy of Conflict and the Economy ad Determinants of Electoral Support in Croatia, Electoral Studies. 42(2), 135-145. https://doi.org/10.1016/j.electstud.2016.02.012

Grdešić, I., Šiber, I., Kasapović, M., i Zakošek. N. (1991). Hrvatska u izborima 1990. Zagreb: Naprijed.

Grdešić, M. (2013). Prostorna analiza 'crvene' i 'crne' Hrvatske: eksplorativna studija. Politička misao, 50(1), 183-203.

Grdešić, M. (2019). Kako je dohodak utjecao na izbor kandidata, kako (ne)zaposlenost i fakultetsko obrazovanje? Ideje.hr. 28. prosinca. https://ideje.hr/kako-je-dohodak-utjecao-na-izbor-kandidata-kako-nezaposlenost-i-fakultetsko-obrazovanje/ 
Henjak, A. (2005). Determinante ideološke samoidentifikacije hrvatskih birača na parlamentarnim izborima 2003. godine. Politička misao, 42(1), 85-110.

Henjak, A. (2008). Values or Interests: Economic Determinants of Voting Behavior in the 2007 Croatian Parliamentary Elections. Politička misao, 44(5), 71-90.

Henjak, A. (2019). Što nam predsjednički izbori mogu reći o političkim trendovima u Hrvatskoj? Revija za sociologiju, 49(3), 419-428.

Hoelscher, S., i Alderman D. (2004). Memory and Place: Geographies of a Critical Relationship. Social and Cultural Geography, 5(3), 347-355. https://doi. org/10.1080/1464936042000252769

Inglehart, R., i Norris, P. (2016). Trump, Brexit and the Rise of Populism: Economic Have-Nots and Cultural Backlash. https://is.muni.cz/el/fss/jaro2018/POL494/ um/premiovy_ukol/Inglehart-Norris-populism.pdf

Institut sinergije znanosti i društva (2014). HR Stat: Hrvatska u boji. https://iszd.hr/ HRstat/

Ivaldi, G., Lanzone. M. E., i Woods. D. (2017). Varieties of Populism Across a Left-Right Spectrum: The Case of the Front National, the Northern League, Podemos and Five Star Movement. Swiss Political Science Review, 23(4), 354-376. https://doi.org/10.1111/spsr.12278

Jennings, W., i Stoker, G. (2016). The Bifurcation of Politics: Two Englands. The Political Quarterly, 87(3), 372-382. https://doi.org/10.1111/1467-923X.12228

Jones, O., i Garde-Hanse, J. (2012) Geography and Memory: Exploration in Identity, Place and Becoming. Houndmills, Basingstoke, Hampshire: Palgrave Macmillan.

Kahneman, D., i Tversky, A. (1979). Prospect Theory: An Analysis of Decision under Risk. Econometrica, 47(2), 263-292.

Koska, V. (2012). Framing the Citizenship Regime Within the Complex Triadic Nexuses: The Case Study of Croatia. Citizenship Studies, 16(3-4), 397-411.

Koska, V., i Matan, A. (2017). Croatian Citizenship Regime and Traumatized Categories of Croatian Citizens: Serb Minority and Croatian Defenders of the Homeland War. Politička misao, 54(1-2), 119-149.

Kučan, V. (1996). Borci Sutjeske. Beograd: Zavod za udžbenike i nastavna sredstva.

Lupu, N., i Peisakhin, L. (2017). The Legacy of Political Violence across Generations. American Journal of Political Science, 61(4), 836-851. https://doi.org/10.1111/ajps.12327

Marcelić, S. (2015). Kritička analiza hrvatskog indeksa razvijenosti: tri tipa razvoja i njihov regionalni položaj. Revija za sociologiju, 22(3), 309-333. https://doi. org/10.3935/rsp.v22i3.1237

McQuarrie, M. (2017). The Revolt of the Rust Belt: Place and Politics in the Age of Anger. British Journal of Sociology, 68(1), S120-S152. https://doi.org/10.1111/14684446.12328

Milas, G., i Rimac, I. (1994). Model hrvatskoga političkog prostora, dimenzioniran stavovima glasača. Revija za sociologiju, 25(1-2), 9-22.

Pop-Eleches, G. (2010). Throwing Out the Bums: Protest, Voting and Unorthodox Parties After Communism. World Politics, 62(2), 221-260. https://doi.org/10.1017/ S0043887110000043

Popović, M. (2021). Total Yugoslav Casualties in World War II (1941-1945). https:// milosp.info/maps/interactive/ww2/index.html 
Raos, V. (2015). Izbori 2015.: jesmo li ušli u razdoblje nestabilnosti i nepreglednosti?. Političke analize, 24(6), 3-11.

Raos, V. (2019). Ideology, Partisanship, and Change: Voter Profiles of Main Political Parties in Croatia. Politička misao, 56(3-4), 7-28. https://doi.org/10.20901/ pm.56.3-4.01

Raos, V. (2020). Struktura rascjepa i parlamentarni izbori u Hrvatskoj 2020. u doba pandemije. Anali Hrvatskog politološkog društva, 17(1), 7-30. https://doi. org/10.20901/an.17.01

Rozenas, A., Schutte, S., i Zhukov, Y. (2017). The Political Legacy of Violence: The Long-Term Impact of Stalin's Repression in Ukraine, The Journal of Politics, 79(4), 1147-1161. https://doi.org/10.1086/692964

Stubager, R. (2008). Education Effects on Authoritarian-Libertarian Values: A Question of Socialization. British Journal of Sociology, 59(2), 327-350. https://doi.org/ 10.1111/j.1468-4446.2008.00196.x

Stubager, R. (2010). The Development of the Education Cleavage: Denmark as a Critical Case. West European Politics, 33(3), 505-533. https://doi.org/10.1080/ 01402381003654544

Šalaj, B. (2014). Analiza potvrdila: Hrvatska se podijelila na plavu (HDZ) i crvenu (SDP). Večernji.hr. 23. svibnja. https://www.vecernji.hr/vijesti/analiza-potvrdila-hrvatska-se-podijelila-na-plavu-hdz-i-crvenu-sdp-940504

Šiber, I. (1997). Izborne orijentacije i ideologijski sukobi tijekom Drugog svjetskog rata: značenje političke biografije obitelji. Politička misao, 34(2), 104-129.

Šiber, I. (1998). Povijesni i etnički rascjepi u hrvatskom društvu. U: M. Kasapović, I. Šiber i N. Zakošek (ur.), Birači i demokracija: utjecaj ideoloških rascjepa na politički život (str. 51-71). Zagreb: Alinea.

Tavits, M., i Letki, N. (2009). When Left is Right: Party Ideology and Policy in Post-Communist Europe. American Political Science Review, 103(2), 555-569. https://doi.org/10.1017/S0003055409990220

Tucker, J. (2006). Regional Economic Voting: Russia, Poland, Hungary, Slovakia, and the Czech Republic, 1990-2000. Cambridge i New York: Cambridge University Press.

Ulrich-Schad, J. D., i Duncan, C. M. (2018). People and Places Left Behind: Work, Culture and Politics in the Rural United States. Journal of Peasant Studies, 45(1), 59-79. https://doi.org/10.1080/03066150.2017.1410702

Vinković, D., i Potočnik, D. (2013). Prve analize statističkih podataka o referendumu 'o braku'. https://iszd.hr/2013/12/prve-analize-statistickih-podataka-o-referendumu-o-braku/

Watson, M. (2018). Brexit, the Left Behind and the Let Down: The Political Abstraction of 'the Economy' and the UK's EU Referendum. British Politics, 13(1), 17-30. https://doi.org/10.1057/s41293-017-0062-8

Zakošek, N. (1994). Struktura i dinamika hrvatskoga stranačkog sustava. Revija za sociologiju, 25(1-2), 23-39.

Zakošek, N. (1998). Ideološki rascjepi i stranačke preferencije hrvatskih birača. U: M. Kasapović, I. Šiber N. i Zakošek (ur.), Birači i demokracija: utjecaj ideoloških rascjepa na politički život (str. 11-49). Zagreb: Alinea. 


\section{Red and Black Croatia in the Long Run}

Abstract One of the best established facts of Croatian politics is the geographical divide between the north-west part of the country which votes for left-wing options and the south-east part of the country which votes for right-wing options. Croatia is not an exception in this regard, as many countries in the region and beyond feature a similar geographical clustering of different political identities. What long-term factors can be used to explain this spatial distribution, the division of the country into a "red Croatia" and a "black Croatia"? This article uses a quantitative analysis of municipal data in order to investigate the impact of three groups of factors: (1) the developmental legacy of socialist Yugoslavia as it existed at the time of the country's dissolution, (2) the deep structural, economic and demographic changes that took place since the end of socialist Yugoslavia until today and (3) the long-run legacies of World War II (1941-1945) and the Homeland War (1991-1995).

Keywords spatial analysis, Croatia, elections, political parties, political geography, municipalities, political identities 


\section{Crvena i crna Hrvatska u dugoročnoj perspektivi: metodološki dodatak}

Metodološki dodatak sadržava dodatne aspekte kvantitativne analize koji bi mogli biti korisni čitateljima. U glavnom se tekstu analiza provodi uz pomoć prostornih regresijskih modela koji su najprikladniji za analizirane podatke. S obzirom na to da se oni nadograđuju na linearne regresijske modele, dodatak prikazuje i rezultate klasičnih linearnih regresijskih modela (OLS). Analiza je, kao i u glavnom tekstu, ponovljena za sve parlamentarne izbore: 2011., 2015., 2016. i 2020. godine. Riječ je o tablicama 7, 8, 9 i 10.

Zatim se analiza širi i na linearne regresijske modele u kojima je zavisna varijabla transformirana u prirodni logaritam. Ovim se postupkom dobiva nešto pravilniji oblik same distribucije za zavisne varijable. Međutim, kao što usporedba ovih i prethodnih modela pokazuje, osnovni se rezultati značajno ne mijenjaju. Doduše, s obzirom na transformiranu zavisnu varijablu, interpretacija se mora ograničiti na statističku značajnost bez sadržajnog tumačenja veličine efekta. Riječ je opet o parlamentarnim izborima 2011., 2015., 2016. i 2020. godine. Rezultati su prikazani u tablicama 11, 12, 13 i 14.

Posljednji modeli su logistički modeli. Zavisna varijabla je transformirana u binarnu varijablu kako bi se dobio jednostavan indikator da li neka geografska cjelina pripada u "crnu" ili u "crvenu" Hrvatsku. Napravljene su dvije verzije takve binarne varijable, a geografski raspored je prikazan u kartama 3 i 4 koje se nalaze u ovom dodatku. U prvoj se verziji rangiranje sastavlja na temelju postotka za desnu opciju na parlamentarnim izborima 2011., 2015., 2016. i 2020. godine. Primjerice, Imotski je u 3 od 4 izbora bio prvi u tom rangiranju, a u četvrtom je slučaju bio drugi. $\mathrm{Na}$ temelju tog poretka svaka općina dobiva bodove za svake izbore. Ti se bodovi zbrajaju za sve izbore. Npr. Imotski dobiva $1+1+1+2=5$ i na temelju toga ima najmanje bodova te je prvi na listi. Labin je posljednji (zbroj rangova za Labin je 98 + $99+99+99=395)$. Prvih 50 se karakterizira kao "crne" općine, a posljednjih 49 kao "crvene" općine.

U drugoj se verziji ne koristi podjela na 50 posto crnih i 50 posto crvenih. Umjesto toga, testira se je li desna opcija dobila veći postotak od lijeve opcije na izborima 2011., 2015., 2016., i 2020. godine. Nakon toga, za sve izbore na kojima je to bio slučaj, općina dobiva (ili ne dobiva) po jedan bod. Općina može dobiti ukupno 4 boda (kao što je primjerice Imotski dobio) ili može dobiti 0 bodova (kao što je Labin dobio). Od toga se izrađuje binarna varijabla: ako općina ima 3 boda ili više dobiva vrijednost 1 , inače dobiva vrijednost 0 . Ukupno je 70 od 99 općina dobilo vrijednost 1 na ovoj varijabli, što znači da je ondje u barem 3 od 4 izbora desna opcija dobila veći postotak glasova od lijeve opcije. Rezultati logističkih modela prikazani su u Tablici 15. 
Tablica 7. Linearni regresijski modeli postotka za različite političke opcije na parlamentarnim izborima 2011. godine

\begin{tabular}{|c|c|c|}
\hline & HDZ 2011. god. & SDP 2011. god. \\
\hline \multicolumn{3}{|l|}{ Naslijeđe Jugoslavije } \\
\hline Udio uzdržavanog stanovništva 1991. godine & $\begin{array}{l}0.574^{*} \\
(0.254)\end{array}$ & $\begin{array}{l}-0.729^{*} \\
(0.281)\end{array}$ \\
\hline $\begin{array}{l}\text { Udio industrijskih radnika u ukupnom } \\
\text { stanovništvu 1991. godine }\end{array}$ & $\begin{array}{l}-0.988^{* * *} \\
(0.224)\end{array}$ & $\begin{array}{c}0.928^{* * *} \\
(0.247)\end{array}$ \\
\hline Udio Srba u ukupnom stanovništvu 1991. godine & $\begin{array}{l}-0.390^{* * *} \\
(0.071)\end{array}$ & $\begin{array}{l}0.355^{* * *} \\
(0.079)\end{array}$ \\
\hline $\begin{array}{l}\text { Udio ateista i nevjernika u ukupnom stanovništvu } \\
\text { 1991. godine }\end{array}$ & $\begin{array}{l}-1.920^{* * *} \\
(0.379)\end{array}$ & $\begin{array}{c}2.762^{* * *} \\
(0.419)\end{array}$ \\
\hline $\begin{array}{l}\text { Udio stanovništva s fakultetskom diplomom } 1991 . \\
\text { godine }\end{array}$ & $\begin{array}{c}0.238 \\
(0.415) \\
\end{array}$ & $\begin{array}{l}-0.409 \\
(0.459) \\
\end{array}$ \\
\hline \multicolumn{3}{|l|}{ Tranzciija od 1991. do 2011. godine } \\
\hline $\begin{array}{l}\text { Promjena u udjelu uzdržavanog stanovništva od } \\
\text { 1991. do 2011. godine }\end{array}$ & $\begin{array}{l}0.583^{* *} \\
(0.209)\end{array}$ & $\begin{array}{l}-0.530^{*} \\
(0.231)\end{array}$ \\
\hline $\begin{array}{l}\text { Promjena u udjelu industrijskih radnika od } 1991 . \\
\text { do 2011. godine }\end{array}$ & $\begin{array}{c}-0.936^{* *} \\
(0.268)\end{array}$ & $\begin{array}{l}1.044^{* *} \\
(0.297)\end{array}$ \\
\hline Promjena u udjelu Srba od 1991. do 2011. godine & $\begin{array}{l}-0.452^{* * *} \\
(0.105)\end{array}$ & $\begin{array}{c}0.456^{* * *} \\
(0.116)\end{array}$ \\
\hline $\begin{array}{l}\text { Promjena u udjelu ateista i nevjernika od 1991. do } \\
\text { 2011. godine }\end{array}$ & $\begin{array}{l}-2.489^{* * *} \\
(0.614)\end{array}$ & $\begin{array}{c}4.059^{* * *} \\
(0.678)\end{array}$ \\
\hline $\begin{array}{l}\text { Promjena u udjelu stanovništva s fakultetskom } \\
\text { diplomom od 1991. do 2011. godine }\end{array}$ & $\begin{array}{l}-0.305 \\
(0.317) \\
\end{array}$ & $\begin{array}{c}0.084 \\
(0.351)\end{array}$ \\
\hline \multicolumn{3}{|l|}{ Naslijeđe ratova } \\
\hline $\begin{array}{l}\text { Broj invalida Domovinskog rata na tisuću } \\
\text { stanovnika (Popis stanovništva iz 2001. godine) }\end{array}$ & $\begin{array}{c}0.428^{* * *} \\
(0.100)\end{array}$ & $\begin{array}{c}-0.371^{* *} \\
(0.111)\end{array}$ \\
\hline $\begin{array}{l}\text { Broj invalida Drugog svjetskog rata na tisuću } \\
\text { stanovnika (Popis stanovništva iz 2001. godine) }\end{array}$ & $\begin{array}{l}1.127^{* *} \\
(0.406)\end{array}$ & $\begin{array}{l}-0.413 \\
(0.448)\end{array}$ \\
\hline Konstanta & $\begin{array}{c}6.162 \\
(12.272)\end{array}$ & $\begin{array}{c}63.264^{* * *} \\
(13.565)\end{array}$ \\
\hline $\mathrm{N}$ & 99 & 99 \\
\hline $\mathrm{F}$ & 24.908 & 24.768 \\
\hline Prilagođeni R na kvadrat & 0.745 & 0.744 \\
\hline
\end{tabular}

Napomena: Koeficijenti i standardne pogreške u zagradama. Statistička značajnost $\mathrm{p}<0.05^{\star}, \mathrm{p}<0.01^{\star *}$, $\mathrm{p}<0.001^{* * *}$ 
Tablica 8. Linearni regresijski modeli postotka za različite političke opcije na parlamentarnim izborima 2015. godine

\begin{tabular}{|c|c|c|c|c|}
\hline & $\begin{array}{l}\text { HDZ } 2015 . \\
\text { god. }\end{array}$ & $\begin{array}{l}\text { SDP } 2015 . \\
\text { god. }\end{array}$ & $\begin{array}{c}\text { Desnica } \\
\text { 2015. god. } \\
\text { (HDZ i } \\
\text { Most) }\end{array}$ & $\begin{array}{l}\text { Ljevica } \\
\text { 2015. god. } \\
\text { (SDP i IDS) }\end{array}$ \\
\hline \multicolumn{5}{|l|}{ Naslijeđe Jugoslavije } \\
\hline $\begin{array}{l}\text { Udio uzdržavanog stanovništva } 1991 . \\
\text { godine }\end{array}$ & $\begin{array}{l}0.747^{\star *} \\
(0.281)\end{array}$ & $\begin{array}{l}-0335 \\
(0.354)\end{array}$ & $\begin{array}{c}0782^{\star} \\
(0.350)\end{array}$ & $\begin{array}{l}-0.452 \\
(0.305)\end{array}$ \\
\hline $\begin{array}{l}\text { Udio industrijskih radnika u ukupnom } \\
\text { stanovništvu 1991. godine }\end{array}$ & $\begin{array}{l}-1.035^{\star * *} \\
(0.247)\end{array}$ & $\begin{array}{l}0.767^{\star} \\
(0.312)\end{array}$ & $\begin{array}{l}-1.344^{* * *} \\
(0.309)\end{array}$ & $\begin{array}{l}0.901^{\star *} \\
(0.269)\end{array}$ \\
\hline $\begin{array}{l}\text { Udio Srba u ukupnom stanovništvu } 1991 . \\
\text { godine }\end{array}$ & $\begin{array}{l}-0.438^{* * *} \\
(0.079)\end{array}$ & $\begin{array}{l}0.329^{* *} \\
(0.099)\end{array}$ & $\begin{array}{l}-0.571^{\star * *} \\
(0.098)\end{array}$ & $\begin{array}{l}0.433^{* * *} \\
(0.085)\end{array}$ \\
\hline $\begin{array}{l}\text { Udio ateista i nevjernika u ukupnom } \\
\text { stanovništvu 1991. godine }\end{array}$ & $\begin{array}{l}-2.705^{* * *} \\
(0.419)\end{array}$ & $\begin{array}{c}0.003 \\
(0.528)\end{array}$ & $\begin{array}{l}-3.515^{* * *} \\
(0.523)\end{array}$ & $\begin{array}{l}3.339^{* * *} \\
(0.455)\end{array}$ \\
\hline $\begin{array}{l}\text { Udio stanovništva s fakultetskom } \\
\text { diplomom 1991. godine } \\
\end{array}$ & $\begin{array}{r}0.297 \\
(0.459) \\
\end{array}$ & $\begin{array}{c}0.563 \\
(0.578) \\
\end{array}$ & $\begin{array}{r}0.895 \\
(0.573) \\
\end{array}$ & $\begin{array}{l}-0.374 \\
(0.498) \\
\end{array}$ \\
\hline \multicolumn{5}{|l|}{ Tranzciija od 1991. do 2011. godine } \\
\hline $\begin{array}{l}\text { Promjena u udjelu uzdržavanog } \\
\text { stanovništva od 1991. do 2011. godine }\end{array}$ & $\begin{array}{l}0.731^{\star *} \\
(0.231)\end{array}$ & $\begin{array}{l}-0.038 \\
(0.291)\end{array}$ & $\begin{array}{l}0.659^{*} \\
(0.288)\end{array}$ & $\begin{array}{l}-0.371 \\
(0.251)\end{array}$ \\
\hline $\begin{array}{l}\text { Promjena u udjelu industrijskih radnika } \\
\text { od 1991. do 2011. godine }\end{array}$ & $\begin{array}{c}-1.133^{* * *} \\
(0.297)\end{array}$ & $\begin{array}{c}0.744 \\
(0.374)\end{array}$ & $\begin{array}{l}-1.560^{* * *} \\
(0.370)\end{array}$ & $\begin{array}{l}0.848^{\star} \\
(0.322)\end{array}$ \\
\hline $\begin{array}{l}\text { Promjena u udjelu Srba od 1991. do } 2011 . \\
\text { godine }\end{array}$ & $\begin{array}{l}-0.578^{* * *} \\
(0.116)\end{array}$ & $\begin{array}{l}0.470^{\star *} \\
(0.147)\end{array}$ & $\begin{array}{l}-0.623^{* * *} \\
(0.145)\end{array}$ & $\begin{array}{l}0.483^{\star * *} \\
(0.126)\end{array}$ \\
\hline $\begin{array}{l}\text { Promjena u udjelu ateista i nevjernika od } \\
\text { 1991. do 2011. godine }\end{array}$ & $\begin{array}{l}-3.433^{* * *} \\
(0.679)\end{array}$ & $\begin{array}{l}-0.199 \\
(0.855)\end{array}$ & $\begin{array}{c}-4.385^{\star * *} \\
(0.847)\end{array}$ & $\begin{array}{c}0.989^{* * *} \\
(0.737)\end{array}$ \\
\hline $\begin{array}{l}\text { Promjena u udjelu stanovništva s } \\
\text { fakultetskom diplomom od 1991. do } 2011 . \\
\text { godine }\end{array}$ & $\begin{array}{c}-0471 \\
(0.351)\end{array}$ & $\begin{array}{c}0.345 \\
(0.442)\end{array}$ & $\begin{array}{c}0.036 \\
(0.438)\end{array}$ & $\begin{array}{c}0.305 \\
(0.381)\end{array}$ \\
\hline \multicolumn{5}{|l|}{ Naslijeđe ratova } \\
\hline $\begin{array}{l}\text { Broj invalida Domovinskog rata na tisuću } \\
\text { stanovnika (Popis stanovništva iz } 2001 . \\
\text { godine) }\end{array}$ & $\begin{array}{c}0.461^{\star * *} \\
(0.111)\end{array}$ & $\begin{array}{c}-0.532^{* * *} \\
(0.140)\end{array}$ & $\begin{array}{c}0.537^{\star \star *} \\
(0.138)\end{array}$ & $\begin{array}{c}-0.557^{\star * *} \\
(0.121)\end{array}$ \\
\hline $\begin{array}{l}\text { Broj invalida Drugog svjetskog rata na } \\
\text { tisuću stanovnika (Popis stanovništva iz } \\
\text { 2001. godine) }\end{array}$ & $\begin{array}{c}0.463 \\
(0.448)\end{array}$ & $\begin{array}{c}0.217 \\
(0.565)\end{array}$ & $\begin{array}{c}0.932 \\
(0.560)\end{array}$ & $\begin{array}{l}-0.154 \\
(0.487)\end{array}$ \\
\hline Konstanta & $\begin{array}{c}13.652 \\
(13.568)\end{array}$ & $\begin{array}{c}39.522^{\star} \\
(17-099)\end{array}$ & $\begin{array}{c}21.965 \\
(16.929)\end{array}$ & $\begin{array}{l}45.022^{\star *} \\
(14.736)\end{array}$ \\
\hline $\mathrm{N}$ & 99 & 99 & 99 & 99 \\
\hline $\mathrm{F}$ & $30.060^{* * *}$ & $6.772^{* * *}$ & $23.196^{* * *}$ & $26.087^{\star * *}$ \\
\hline Prilagođeni R na kvadrat & 0.781 & 0.414 & 0.731 & 0.754 \\
\hline
\end{tabular}

Napomena: Koeficijenti i standardne pogreške u zagradama. Statistička značajnost $\mathrm{p}<0.05^{\star}, \mathrm{p}<0.01^{\star *}$, $\mathrm{p}<0.001^{* * *}$ 
Tablica 9. Linearni regresijski modeli postotka za različite političke opcije na parlamentarnim izborima 2016. godine

\begin{tabular}{|c|c|c|c|c|}
\hline & $\begin{array}{l}\text { HDZ } 2016 . \\
\text { god. }\end{array}$ & $\begin{array}{l}\text { SDP } 2016 . \\
\text { god. }\end{array}$ & $\begin{array}{l}\text { Desnica } \\
\text { 2016. god. } \\
\text { (HDZ i } \\
\text { Most) }\end{array}$ & $\begin{array}{c}\text { Ljevica } \\
\text { 2016. god. } \\
\text { (SDP i IDS) }\end{array}$ \\
\hline \multicolumn{5}{|l|}{ Naslijeđe Jugoslavije } \\
\hline $\begin{array}{l}\text { Udio uzdržavanog stanovništva } 1991 . \\
\text { godine }\end{array}$ & $\begin{array}{l}0.701^{\star} \\
(0.270)\end{array}$ & $\begin{array}{l}-0.526 \\
(0.363)\end{array}$ & $\begin{array}{l}0.768^{\star} \\
(0.344)\end{array}$ & $\begin{array}{l}-0.637^{\star} \\
(0.305)\end{array}$ \\
\hline $\begin{array}{l}\text { Udio industrijskih radnika u ukupnom } \\
\text { stanovništvu 1991. godine }\end{array}$ & $\begin{array}{c}-1.142^{* * *} \\
(0.238)\end{array}$ & $\begin{array}{l}0.844^{*} \\
(0.320)\end{array}$ & $\begin{array}{l}-1.507^{\star * *} \\
(0.303)\end{array}$ & $\begin{array}{l}0.973^{\star *} \\
(0.269)\end{array}$ \\
\hline $\begin{array}{l}\text { Udio Srba u ukupnom stanovništvu } 1991 . \\
\text { godine }\end{array}$ & $\begin{array}{l}-0.394^{* * *} \\
(0.076)\end{array}$ & $\begin{array}{l}0.250^{*} \\
(0.102)\end{array}$ & $\begin{array}{c}-1.507^{\star * *} \\
(0.096)\end{array}$ & $\begin{array}{l}0.364^{* * *} \\
(0.085)\end{array}$ \\
\hline $\begin{array}{l}\text { Udio ateista i nevjernika u ukupnom } \\
\text { stanovništvu 1991. godine }\end{array}$ & $\begin{array}{l}-2.412^{\star * *} \\
(0.404)\end{array}$ & $\begin{array}{l}-0.366 \\
(0.542)\end{array}$ & $\begin{array}{l}-3.288^{* * *} \\
(0.513)\end{array}$ & $\begin{array}{l}3.260^{* * *} \\
(0.456)\end{array}$ \\
\hline $\begin{array}{l}\text { Udio stanovništva s fakultetskom } \\
\text { diplomom 1991. godine }\end{array}$ & $\begin{array}{c}0.268 \\
(0.442) \\
\end{array}$ & $\begin{array}{r}0.337 \\
(0.593) \\
\end{array}$ & $\begin{array}{c}0.847 \\
(0.562) \\
\end{array}$ & $\begin{array}{l}-0.592 \\
(0.499) \\
\end{array}$ \\
\hline \multicolumn{5}{|l|}{ Tranzciija od 1991. do 2011. godine } \\
\hline $\begin{array}{l}\text { Promjena u udjelu uzdržavanog } \\
\text { stanovništva od 1991. do 2011. godine }\end{array}$ & $\begin{array}{l}0.682^{\star *} \\
(0.223)\end{array}$ & $\begin{array}{l}-0.120 \\
(0.299)\end{array}$ & $\begin{array}{l}0.633^{\star} \\
(0.283)\end{array}$ & $\begin{array}{l}-0.463 \\
(0.251)\end{array}$ \\
\hline $\begin{array}{l}\text { Promjena u udjelu industrijskih radnika } \\
\text { od 1991. do 2011. godine }\end{array}$ & $\begin{array}{l}-1.267^{\star * *} \\
(0.268)\end{array}$ & $\begin{array}{l}0.870^{\star} \\
(0.384)\end{array}$ & $\begin{array}{c}-1.796^{* * *} \\
(0.363)\end{array}$ & $\begin{array}{l}0.982^{\star *} \\
(0.322)\end{array}$ \\
\hline $\begin{array}{l}\text { Promjena u udjelu Srba od 1991. do } 2011 . \\
\text { godine }\end{array}$ & $\begin{array}{c}-0.483^{* * *} \\
(0.112)\end{array}$ & $\begin{array}{l}0.326^{*} \\
(0.150)\end{array}$ & $\begin{array}{c}-0.496^{\star *} \\
(0.142)\end{array}$ & $\begin{array}{l}0.337^{\star *} \\
(0.126)\end{array}$ \\
\hline $\begin{array}{l}\text { Promjena u udjelu ateista i nevjernika od } \\
\text { 1991. do 2011. godine }\end{array}$ & $\begin{array}{c}-3.109^{* * *} \\
(0.654)\end{array}$ & $\begin{array}{l}-0.716 \\
(0.877)\end{array}$ & $\begin{array}{c}-4.161^{* * *} \\
(0.831)\end{array}$ & $\begin{array}{c}5.002^{\star * *} \\
(0.737)\end{array}$ \\
\hline $\begin{array}{l}\text { Promjena u udjelu stanovništva s } \\
\text { fakultetskom diplomom od 1991. do } 2011 . \\
\text { godine }\end{array}$ & $\begin{array}{l}-0.213 \\
(0.338)\end{array}$ & $\begin{array}{c}0.133 \\
(0.454)\end{array}$ & $\begin{array}{l}-0.109 \\
(0.430)\end{array}$ & $\begin{array}{c}0.110 \\
(0.381)\end{array}$ \\
\hline \multicolumn{5}{|l|}{ Naslijeđe ratova } \\
\hline $\begin{array}{l}\text { Broj invalida Domovinskog rata na tisuću } \\
\text { stanovnika (Popis stanovništva iz } 2001 . \\
\text { godine) }\end{array}$ & $\begin{array}{c}0.530^{* * *} \\
(0.107)\end{array}$ & $\begin{array}{c}-0.631^{\star * *} \\
(0.143)\end{array}$ & $\begin{array}{c}0.612^{\star * *} \\
(0.136)\end{array}$ & $\begin{array}{c}-0.661^{\star * *} \\
(0.121)\end{array}$ \\
\hline $\begin{array}{l}\text { Broj invalida Drugog svjetskog rata na } \\
\text { tisuću stanovnika (Popis stanovništva iz } \\
\text { 2001. godine) }\end{array}$ & $\begin{array}{c}0.703 \\
(0.432)\end{array}$ & $\begin{array}{l}-0.363 \\
(0.580)\end{array}$ & $\begin{array}{c}1.360^{*} \\
(0.549)\end{array}$ & $\begin{array}{l}-0.786 \\
(0.487)\end{array}$ \\
\hline Konstanta & $\begin{array}{c}14.251 \\
(13.069)\end{array}$ & $\begin{array}{l}52.767^{\star *} \\
(17.537)\end{array}$ & $\begin{array}{c}20.963 \\
(16.618)\end{array}$ & $\begin{array}{c}57.689^{* * *} \\
(14.744)\end{array}$ \\
\hline $\mathrm{N}$ & 99 & 99 & 99 & 99 \\
\hline $\mathrm{F}$ & $30.881^{\star * *}$ & $7.251^{\star * *}$ & $25.852^{* * *}$ & $28.691^{\star * *}$ \\
\hline Prilagođeni R na kvadrat & 0.785 & 0.434 & 0.753 & 0.772 \\
\hline
\end{tabular}

Napomena: Koeficijenti i standardne pogreške u zagradama. Statistička značajnost $\mathrm{p}<0.05^{\star}, \mathrm{p}<0.01^{\star *}$, $\mathrm{p}<0.001^{* * *}$ 
Tablica 10. Linearni regresijski modeli postotka za različite političke opcije na parlamentarnim izborima 2020. godine

\begin{tabular}{|c|c|c|c|c|}
\hline & $\begin{array}{l}\text { HDZ } 2020 . \\
\text { god. }\end{array}$ & $\begin{array}{l}\text { SDP } 2020 . \\
\text { god. }\end{array}$ & $\begin{array}{l}\text { Desnica } \\
\text { 2020. god. } \\
\text { (HDZ, Most } \\
\text { i DP) } \\
\end{array}$ & $\begin{array}{c}\text { Ljevica } 2020 . \\
\text { god. (SDP i } \\
\text { Možemo!) }\end{array}$ \\
\hline \multicolumn{5}{|l|}{ Naslijeđe Jugoslavije } \\
\hline $\begin{array}{l}\text { Udio uzdržavanog stanovništva } 1991 . \\
\text { godine }\end{array}$ & $\begin{array}{l}0.791^{\star *} \\
(0.256)\end{array}$ & $\begin{array}{l}-0.330 \\
(0.307)\end{array}$ & $\begin{array}{l}0.865^{\star} \\
(0.380)\end{array}$ & $\begin{array}{l}-0.472 \\
(0.320)\end{array}$ \\
\hline $\begin{array}{l}\text { Udio industrijskih radnika u ukupnom } \\
\text { stanovništvu 1991. godine }\end{array}$ & $\begin{array}{c}-0.714^{* *} \\
(0.226)\end{array}$ & $\begin{array}{l}0.790^{\star *} \\
(0.271)\end{array}$ & $\begin{array}{c}-1.145^{* *} \\
(0.335)\end{array}$ & $\begin{array}{l}0.786^{\star *} \\
(0.282)\end{array}$ \\
\hline $\begin{array}{l}\text { Udio Srba u ukupnom stanovništvu } 1991 . \\
\text { godine }\end{array}$ & $\begin{array}{l}-0.268^{* * *} \\
(0.072)\end{array}$ & $\begin{array}{l}0.258^{* *} \\
(0.086)\end{array}$ & $\begin{array}{c}-0.261^{\star} \\
(0.106)\end{array}$ & $\begin{array}{l}0.295^{\star *} \\
(0.089)\end{array}$ \\
\hline $\begin{array}{l}\text { Udio ateista i nevjernika u ukupnom } \\
\text { stanovništvu 1991. godine }\end{array}$ & $\begin{array}{c}-2.402^{* * *} \\
(0.383)\end{array}$ & $\begin{array}{c}3.245^{* * *} \\
(0.459)\end{array}$ & $\begin{array}{c}-3.638^{* * *} \\
(0.567)\end{array}$ & $\begin{array}{c}3.707^{* * *} \\
(0.478)\end{array}$ \\
\hline $\begin{array}{l}\text { Udio stanovništva s fakultetskom } \\
\text { diplomom 1991. godine }\end{array}$ & $\begin{array}{c}0.435 \\
(0.419) \\
\end{array}$ & $\begin{array}{l}-0.601 \\
(0.502) \\
\end{array}$ & $\begin{array}{c}0.786 \\
(0.621) \\
\end{array}$ & $\begin{array}{l}-0.738 \\
(0.523) \\
\end{array}$ \\
\hline \multicolumn{5}{|l|}{ Tranzciija od 1991. do 2011. godine } \\
\hline $\begin{array}{l}\text { Promjena u udjelu uzdržavanog } \\
\text { stanovništva od 1991. do 2011. godine }\end{array}$ & $\begin{array}{l}0.682^{\star *} \\
(0.211)\end{array}$ & $\begin{array}{l}-0.280 \\
(0.253)\end{array}$ & $\begin{array}{c}0.590 \\
(0.313)\end{array}$ & $\begin{array}{l}-0.392 \\
(0.263)\end{array}$ \\
\hline $\begin{array}{l}\text { Promjena u udjelu industrijskih radnika } \\
\text { od 1991. do 2011. godine }\end{array}$ & $\begin{array}{c}-0.573^{*} \\
(0.271)\end{array}$ & $\begin{array}{l}0.860^{*} \\
(0.325)\end{array}$ & $\begin{array}{l}-1.213^{* *} \\
(0.402)\end{array}$ & $\begin{array}{l}0.885^{*} \\
(0.338)\end{array}$ \\
\hline $\begin{array}{l}\text { Promjena u udjelu Srba od 1991. do } 2011 . \\
\text { godine }\end{array}$ & $\begin{array}{c}-0.376^{* *} \\
(0.106)\end{array}$ & $\begin{array}{l}0.271^{\star} \\
(0.127)\end{array}$ & $\begin{array}{l}-0.346^{*} \\
(0.157)\end{array}$ & $\begin{array}{c}0.253 \\
(0.132)\end{array}$ \\
\hline $\begin{array}{l}\text { Promjena u udjelu ateista i nevjernika od } \\
\text { 1991. do 2011. godine }\end{array}$ & $\begin{array}{c}-3.182^{* * *} \\
(0.620)\end{array}$ & $\begin{array}{l}4.473^{* * *} \\
(0.742)\end{array}$ & $\begin{array}{c}-5.327^{* * *} \\
(0.918)\end{array}$ & $\begin{array}{c}4.969^{* * *} \\
(0.773)\end{array}$ \\
\hline $\begin{array}{l}\text { Promjena u udjelu stanovništva s } \\
\text { fakultetskom diplomom od 1991. do } 2011 . \\
\text { godine }\end{array}$ & $\begin{array}{l}-0.416 \\
0.321)\end{array}$ & $\begin{array}{l}-0.139 \\
(0.384)\end{array}$ & $\begin{array}{l}-0.452 \\
(0.475)\end{array}$ & $\begin{array}{c}0.534 \\
(0.400)\end{array}$ \\
\hline \multicolumn{5}{|l|}{ Naslijeđe ratova } \\
\hline $\begin{array}{l}\text { Broj invalida Domovinskog rata na tisuću } \\
\text { stanovnika (Popis stanovništva iz } 2001 . \\
\text { godine) }\end{array}$ & $\begin{array}{l}0.334^{* *} \\
(0.101)\end{array}$ & $\begin{array}{c}-0.399^{* *} \\
(0.121)\end{array}$ & $\begin{array}{l}0.520^{\star *} \\
(0.150)\end{array}$ & $\begin{array}{c}-0.425^{\star \star} \\
(0.126)\end{array}$ \\
\hline $\begin{array}{l}\text { Broj invalida Drugog svjetskog rata na } \\
\text { tisuću stanovnika (Popis stanovništva iz } \\
\text { 2001. godine) }\end{array}$ & $\begin{array}{c}0.482 \\
(0.410)\end{array}$ & $\begin{array}{l}-0.252 \\
(0.491)\end{array}$ & $\begin{array}{l}-0.002 \\
(0.607)\end{array}$ & $\begin{array}{l}-0.450 \\
(0.511)\end{array}$ \\
\hline Konstanta & $\begin{array}{c}12.723 \\
(12.399)\end{array}$ & $\begin{array}{l}35.091^{\star} \\
(14.841)\end{array}$ & $\begin{array}{c}31.886 \\
(18.364)\end{array}$ & $\begin{array}{l}31.036^{* *} \\
(15.458)\end{array}$ \\
\hline $\mathrm{N}$ & 99 & 99 & 99 & 99 \\
\hline $\mathrm{F}$ & $26.594^{* * *}$ & $17.193^{\star * *}$ & $22.924^{* * *}$ & $21.249^{* * *}$ \\
\hline Prilagođeni R na kvadrat & 0.758 & 0.665 & 0.729 & 0.713 \\
\hline
\end{tabular}

Napomena: Koeficijenti i standardne pogreške u zagradama. Statistička značajnost $\mathrm{p}<0.05^{\star}, \mathrm{p}<0.01^{\star *}$, $\mathrm{p}<0.001^{* * *}$ 
Tablica 11. Linearni regresijski modeli postotka za različite političke opcije na parlamentarnim izborima 2011. godine (zavisna varijabla je prirodni logaritam izvorne zavisne varijable)

\begin{tabular}{|c|c|c|}
\hline & $\begin{array}{l}\text { HDZ 2011. god. } \\
(\ln )\end{array}$ & $\begin{array}{l}\text { SDP 2011. god } \\
\text { (ln) }\end{array}$ \\
\hline \multicolumn{3}{|l|}{ Naslijeđe Jugoslavije } \\
\hline Udio uzdržavanog stanovništva 1991. godine & $\begin{array}{l}0.022^{*} \\
(0.010)\end{array}$ & $\begin{array}{l}-0.020^{*} \\
(0.009)\end{array}$ \\
\hline $\begin{array}{l}\text { Udio industrijskih radnika u ukupnom stanovništvu } \\
\text { 1991. godine }\end{array}$ & $\begin{array}{l}-0.042^{* * *} \\
(0.009)\end{array}$ & $\begin{array}{l}0.026^{* *} \\
(0.008)\end{array}$ \\
\hline Udio Srba u ukupnom stanovništvu 1991. godine & $\begin{array}{l}-0.015^{* * *} \\
(0.003)\end{array}$ & $\begin{array}{c}0.010^{* * *} \\
(0003)\end{array}$ \\
\hline $\begin{array}{l}\text { Udio ateista i nevjernika u ukupnom stanovništvu } \\
\text { 1991. godine }\end{array}$ & $\begin{array}{l}-0.112^{* * *} \\
(0.015)\end{array}$ & $\begin{array}{l}0.065^{* * *} \\
(0.013)\end{array}$ \\
\hline $\begin{array}{l}\text { Udio stanovništva s fakultetskom diplomom } 1991 . \\
\text { godine }\end{array}$ & $\begin{array}{c}0.020 \\
(0.017)\end{array}$ & $\begin{array}{l}-0.008 \\
(0.015)\end{array}$ \\
\hline \multicolumn{3}{|l|}{ Tranzicija od 1991. do 2011. godine } \\
\hline $\begin{array}{l}\text { Promjena u udjelu uzdržavanog stanovništva od } \\
\text { 1991. do 2011. godine }\end{array}$ & $\begin{array}{l}0.022^{*} \\
(0.008)\end{array}$ & $\begin{array}{l}-0.016^{*} \\
(0.007)\end{array}$ \\
\hline $\begin{array}{l}\text { Promjena u udjelu industrijskih radnika od 1991. do } \\
\text { 2011. godine }\end{array}$ & $\begin{array}{l}-0.038^{* *} \\
(0.011)\end{array}$ & $\begin{array}{l}0.030^{* *} \\
(0.010)\end{array}$ \\
\hline Promjena u udjelu Srba od 1991. do 2011. godine & $\begin{array}{l}-0.015^{* * *} \\
(0.004)\end{array}$ & $\begin{array}{c}0.014^{* * *} \\
(0.004)\end{array}$ \\
\hline $\begin{array}{l}\text { Promjena u udjelu ateista i nevjernika od 1991. do } \\
\text { 2011. godine }\end{array}$ & $\begin{array}{l}-0.176^{* * *} \\
(0.025)\end{array}$ & $\begin{array}{c}0.085^{* * *} \\
(0.022)\end{array}$ \\
\hline $\begin{array}{l}\text { Promjena u udjelu stanovništva s fakultetskom } \\
\text { diplomom od 1991. do 2011. godine }\end{array}$ & $\begin{array}{l}-0.016 \\
(0.013) \\
\end{array}$ & $\begin{array}{c}0.002 \\
(0.011) \\
\end{array}$ \\
\hline \multicolumn{3}{|l|}{ Naslijeđe ratova } \\
\hline $\begin{array}{l}\text { Broj invalida Domovinskog rata na tisuću stanovnika } \\
\text { (Popis stanovništva iz 2001. godine) }\end{array}$ & $\begin{array}{l}0.014^{* *} \\
(0.016)\end{array}$ & $\begin{array}{l}-0.010^{* *} \\
(0.004)\end{array}$ \\
\hline $\begin{array}{l}\text { Broj invalida Drugog svjetskog rata na tisuću } \\
\text { stanovnika (Popis stanovništva iz 2001. godine) }\end{array}$ & $\begin{array}{l}0.042^{\star} \\
(0.016)\end{array}$ & $\begin{array}{l}-0.008 \\
(0.014)\end{array}$ \\
\hline Konstanta & $\begin{array}{c}2.550^{* * *} \\
(0.493)\end{array}$ & $\begin{array}{l}4.300^{* * *} \\
(0.437)\end{array}$ \\
\hline $\mathrm{N}$ & 99 & 99 \\
\hline $\mathrm{F}$ & $30.447^{* * *}$ & $15.981^{\star * *}$ \\
\hline Prilagođeni R na kvadrat & 0.783 & 0.647 \\
\hline
\end{tabular}

Napomena: Koeficijenti i standardne pogreške u zagradama. Statistička značajnost $\mathrm{p}<0.05^{\star}, \mathrm{p}<0.01^{\star *}$, $\mathrm{p}<0.001^{* * *}$ 
Tablica 12. Linearni regresijski modeli postotka za različite političke opcije na parlamentarnim izborima 2015. godine (zavisna varijabla je prirodni logaritam izvorne zavisne varijable)

\begin{tabular}{|c|c|c|c|c|}
\hline & $\begin{array}{l}\text { HDZ } 2015 . \\
\quad \text { god } \\
(\ln )\end{array}$ & $\begin{array}{l}\text { DP 2015. god } \\
(\ln )\end{array}$ & $\begin{array}{c}\text { Desnica } \\
\text { 2015. god. } \\
\text { (HDZ i Most) } \\
(\ln ) \\
\end{array}$ & $\begin{array}{l}\text { Ljevica } 2015 . \\
\text { god. (SDP i } \\
\text { IDS) } \\
\text { (ln) } \\
\end{array}$ \\
\hline \multicolumn{5}{|l|}{ Naslijeđe Jugoslavije } \\
\hline $\begin{array}{l}\text { Udio uzdržavanog stanovništva } 1991 . \\
\text { godine }\end{array}$ & $\begin{array}{l}0.019^{\star} \\
(0.009)\end{array}$ & $\begin{array}{l}-0.013 \\
(0.012)\end{array}$ & $\begin{array}{c}0.014 \\
(0.008)\end{array}$ & $\begin{array}{l}-0.017 \\
(0.010)\end{array}$ \\
\hline $\begin{array}{l}\text { Udio industrijskih radnika u ukupnom } \\
\text { stanovništvu 1991. godine }\end{array}$ & $\begin{array}{l}-0.032^{* * *} \\
(0.008)\end{array}$ & $\begin{array}{l}0.027^{\star} \\
(0.011)\end{array}$ & $\begin{array}{c}-0.032^{\star * *} \\
(0.007)\end{array}$ & $\begin{array}{l}0.029^{* *} \\
(0.009)\end{array}$ \\
\hline $\begin{array}{l}\text { Udio Srba u ukupnom stanovništvu } 1991 . \\
\text { godine }\end{array}$ & $\begin{array}{l}-0.013^{\star * *} \\
(0.003)\end{array}$ & $\begin{array}{l}0.010^{* *} \\
(0.003)\end{array}$ & $\begin{array}{l}-0.013^{\star * *} \\
(0.002)\end{array}$ & $\begin{array}{c}0.013^{\star * *} \\
(0.003)\end{array}$ \\
\hline $\begin{array}{l}\text { Udio ateista i nevjernika u ukupnom } \\
\text { stanovništvu 1991. godine }\end{array}$ & $\begin{array}{l}-0.117^{* * *} \\
(0.014)\end{array}$ & $\begin{array}{c}0.012 \\
(0.018)\end{array}$ & $\begin{array}{l}-0.099^{* * *} \\
(0.013)\end{array}$ & $\begin{array}{l}0.084^{* * *} \\
(0.015)\end{array}$ \\
\hline $\begin{array}{l}\text { Udio stanovništva s fakultetskom } \\
\text { diplomom 1991. godine }\end{array}$ & $\begin{array}{c}0.020 \\
(0.015) \\
\end{array}$ & $\begin{array}{c}0.014 \\
(0.020) \\
\end{array}$ & $\begin{array}{c}0.025 \\
(0.014) \\
\end{array}$ & $\begin{array}{l}-0.007 \\
(0.016)\end{array}$ \\
\hline \multicolumn{5}{|l|}{ Tranzicija od 1991. do 2011. godine } \\
\hline $\begin{array}{l}\text { Promjena u udjelu uzdržavanog } \\
\text { stanovništva od 1991. do 2011. godine }\end{array}$ & $\begin{array}{l}0.020^{*} \\
(0.008)\end{array}$ & $\begin{array}{l}-0.006 \\
(0.010)\end{array}$ & $\begin{array}{c}0.014 \\
(0.007)\end{array}$ & $\begin{array}{l}-0.014 \\
(0.008)\end{array}$ \\
\hline $\begin{array}{l}\text { Promjena u udjelu industrijskih radnika } \\
\text { od 1991. do 2011. godine }\end{array}$ & $\begin{array}{c}-0.034^{* *} \\
(0.010)\end{array}$ & $\begin{array}{l}0.028^{*} \\
(0.013)\end{array}$ & $\begin{array}{l}-0.035^{* * *} \\
(0.009)\end{array}$ & $\begin{array}{l}0.030^{* *} \\
(0.011)\end{array}$ \\
\hline $\begin{array}{l}\text { Promjena u udjelu Srba od 1991. do } 2011 . \\
\text { godine }\end{array}$ & $\begin{array}{l}-0.015^{* * *} \\
(0.004)\end{array}$ & $\begin{array}{l}0.013^{*} \\
(0.005)\end{array}$ & $\begin{array}{l}-0.014^{* * *} \\
(0.003)\end{array}$ & $\begin{array}{l}0.013^{* *} \\
(0.004)\end{array}$ \\
\hline $\begin{array}{l}\text { Promjena u udjelu ateista i nevjernika od } \\
\text { 1991. do 2011. godine }\end{array}$ & $\begin{array}{l}-0.178^{* * *} \\
(0.023)\end{array}$ & $\begin{array}{l}-0.002 \\
(0.029)\end{array}$ & $\begin{array}{l}-0.143^{* * *} \\
(0.020)\end{array}$ & $\begin{array}{c}0.110^{* * *} \\
(0.024)\end{array}$ \\
\hline $\begin{array}{l}\text { Promjena u udjelu stanovništva s } \\
\text { fakultetskom diplomom od 1991. do } 2011 . \\
\text { godine }\end{array}$ & $\begin{array}{l}-0.017 \\
(0.012)\end{array}$ & $\begin{array}{c}0.010 \\
(0.015)\end{array}$ & $\begin{array}{l}-0.001 \\
(0.011)\end{array}$ & $\begin{array}{c}0.009 \\
(0.013)\end{array}$ \\
\hline \multicolumn{5}{|l|}{ Naslijede ratova } \\
\hline $\begin{array}{l}\text { Broj invalida Domovinskog rata na tisuću } \\
\text { stanovnika (Popis stanovništva iz } 2001 . \\
\text { godine) }\end{array}$ & $\begin{array}{l}0.011^{\star *} \\
(0.004)\end{array}$ & $\begin{array}{l}-0.016^{\star *} \\
(0.005)\end{array}$ & $\begin{array}{l}0.011^{\star \star} \\
(0.003)\end{array}$ & $\begin{array}{l}-0.016^{* * *} \\
(0.004)\end{array}$ \\
\hline $\begin{array}{l}\text { Broj invalida Drugog svjetskog rata na } \\
\text { tisuću stanovnika (Popis stanovništva iz } \\
\text { 2001. godine) }\end{array}$ & $\begin{array}{c}0.015 \\
(0.015)\end{array}$ & $\begin{array}{c}0.005 \\
(0.019)\end{array}$ & $\begin{array}{c}0.018 \\
(0.013)\end{array}$ & $\begin{array}{c}0.003 \\
(0.016)\end{array}$ \\
\hline Konstanta & $\begin{array}{l}3.051^{* * *} \\
(0.452)\end{array}$ & $\begin{array}{l}3.751^{\star * *} \\
(0.586)\end{array}$ & $\begin{array}{l}3.431^{\star * *} \\
(0.408)\end{array}$ & $\begin{array}{l}3.919^{* * *} \\
(0.487)\end{array}$ \\
\hline $\mathrm{N}$ & 99 & 99 & 99 & 99 \\
\hline $\mathrm{F}$ & $30.355^{\star * *}$ & $5.518^{* * *}$ & $24.44^{* * *}$ & $17.765^{* * *}$ \\
\hline Prilagođeni R na kvadrat & 0.782 & 0.356 & 0.742 & 0.672 \\
\hline
\end{tabular}

Napomena: Koeficijenti i standardne pogreške u zagradama. Statistička značajnost $\mathrm{p}<0.05^{*}, \mathrm{p}<0.01^{\star *}$, $\mathrm{p}<0.001^{* * *}$ 
Tablica 13. Linearni regresijski modeli postotka za različite političke opcije na parlamentarnim izborima 2016. godine (zavisna varijabla je prirodni logaritam izvorne zavisne varijable)

\begin{tabular}{|c|c|c|c|c|}
\hline & $\begin{array}{l}\text { HDZ } 2016 . \\
\text { god } \\
(\ln )\end{array}$ & $\begin{array}{l}\text { SDP } 2016 . \\
\text { god. } \\
(\ln )\end{array}$ & $\begin{array}{c}\text { Desnica } \\
\text { 2016. god. } \\
\text { (HDZ i Most) } \\
(\ln ) \\
\end{array}$ & $\begin{array}{l}\text { Ljevica } 2016 . \\
\operatorname{god}(\text { SDP i } \\
\text { IDS) } \\
\text { (ln) } \\
\end{array}$ \\
\hline \multicolumn{5}{|l|}{ Naslijeđe Jugoslavije } \\
\hline $\begin{array}{l}\text { Udio uzdržavanog stanovništva } 1991 . \\
\text { godine }\end{array}$ & $\begin{array}{l}0.018^{\star} \\
(0.008)\end{array}$ & $\begin{array}{l}-0.018 \\
(0.013)\end{array}$ & $\begin{array}{l}0.016^{*} \\
(0.008)\end{array}$ & $\begin{array}{c}-0.021^{*} \\
(0.010)\end{array}$ \\
\hline $\begin{array}{l}\text { Udio industrijskih radnika u ukupnom } \\
\text { stanovništvu 1991. godine }\end{array}$ & $\begin{array}{l}-.035^{* * *} \\
(0.007)\end{array}$ & $\begin{array}{l}0.027^{*} \\
(0.011)\end{array}$ & $\begin{array}{l}-0.036^{* * *} \\
(0.007)\end{array}$ & $\begin{array}{l}0.030^{* *} \\
(0.009)\end{array}$ \\
\hline $\begin{array}{l}\text { Udio Srba u ukupnom stanovništvu } 1991 . \\
\text { godine }\end{array}$ & $\begin{array}{l}-0.010^{* * *} \\
(0.002)\end{array}$ & $\begin{array}{l}0.009^{*} \\
(0.004)\end{array}$ & $\begin{array}{l}-0.011^{* * *} \\
(0.002)\end{array}$ & $\begin{array}{l}0.011^{* * *} \\
(0.003)\end{array}$ \\
\hline $\begin{array}{l}\text { Udio ateista i nevjernika u ukupnom } \\
\text { stanovništvu 1991. godine }\end{array}$ & $\begin{array}{l}-0.099^{* * *} \\
(0.013)\end{array}$ & $\begin{array}{l}-0.001 \\
(0.019)\end{array}$ & $\begin{array}{c}-0.096^{* * *} \\
(0.012)\end{array}$ & $\begin{array}{l}0.079^{* * *} \\
(0.015)\end{array}$ \\
\hline $\begin{array}{l}\text { Udio stanovništva s fakultetskom } \\
\text { diplomom 1991. godine }\end{array}$ & $\begin{array}{c}0.018 \\
(0.014) \\
\end{array}$ & $\begin{array}{c}0.011 \\
(0.020) \\
\end{array}$ & $\begin{array}{c}0.025 \\
(0.013) \\
\end{array}$ & $\begin{array}{l}-0.010 \\
(0.017) \\
\end{array}$ \\
\hline \multicolumn{5}{|l|}{ Tranzicija od 1991. do 2011. godine } \\
\hline $\begin{array}{l}\text { Promjena u udjelu uzdržavanog } \\
\text { stanovništva od 1991. do 2011. godine }\end{array}$ & $\begin{array}{l}0.018^{*} \\
(0.007)\end{array}$ & $\begin{array}{l}-0.007 \\
(0.010)\end{array}$ & $\begin{array}{l}0.014^{*} \\
(0.007)\end{array}$ & $\begin{array}{l}-0.015 \\
(0.008)\end{array}$ \\
\hline $\begin{array}{l}\text { Promjena u udjelu industrijskih radnika } \\
\text { od 1991. do 2011. godine }\end{array}$ & $\begin{array}{l}-0.037^{* * *} \\
(0.009)\end{array}$ & $\begin{array}{l}0.031^{*} \\
(0.013)\end{array}$ & $\begin{array}{l}-0.040^{* * *} \\
(0.008)\end{array}$ & $\begin{array}{l}0.033^{* *} \\
(0.011)\end{array}$ \\
\hline $\begin{array}{l}\text { Promjena u udjelu Srba od 1991. do } 2011 . \\
\text { godine }\end{array}$ & $\begin{array}{c}-0.011^{\star *} \\
(0.003)\end{array}$ & $\begin{array}{l}0.011^{*} \\
(0.005)\end{array}$ & $\begin{array}{l}-0.010^{* *} \\
(0.003)\end{array}$ & $\begin{array}{l}0.011^{\star} \\
(0.004)\end{array}$ \\
\hline $\begin{array}{l}\text { Promjena u udjelu ateista i nevjernika od } \\
\text { 1991. do 2011. godine }\end{array}$ & $\begin{array}{c}-0.151^{\star * *} \\
(0.020)\end{array}$ & $\begin{array}{l}-0.024 \\
(0.030)\end{array}$ & $\begin{array}{c}-0.140^{\star * *} \\
(0.019)\end{array}$ & $\begin{array}{c}0.102^{* * *} \\
(0.025)\end{array}$ \\
\hline $\begin{array}{l}\text { Promjena u udjelu stanovništva s } \\
\text { fakultetskom diplomom od 1991. do } 2011 . \\
\text { godine }\end{array}$ & $\begin{array}{l}-0.007 \\
(0.011)\end{array}$ & $\begin{array}{c}0.004 \\
(0.016)\end{array}$ & $\begin{array}{l}-0.002 \\
(0.010)\end{array}$ & $\begin{array}{c}0.004 \\
(0.013)\end{array}$ \\
\hline \multicolumn{5}{|l|}{ Naslijeđe ratova } \\
\hline $\begin{array}{l}\text { Broj invalida Domovinskog rata na tisuću } \\
\text { stanovnika (Popis stanovništva iz } 2001 . \\
\text { godine) }\end{array}$ & $\begin{array}{l}0.012^{\star *} \\
(0.003)\end{array}$ & $\begin{array}{c}-0.020^{* * *} \\
(0.005)\end{array}$ & $\begin{array}{l}0.012^{* * *} \\
(0.003)\end{array}$ & $\begin{array}{c}-0.021^{* * *} \\
(0.004)\end{array}$ \\
\hline $\begin{array}{l}\text { Broj invalida Drugog svjetskog rata na } \\
\text { tisuću stanovnika (Popis stanovništva iz } \\
\text { 2001. godine) }\end{array}$ & $\begin{array}{c}0.020 \\
(0.013)\end{array}$ & $\begin{array}{l}-0.011 \\
(0.020)\end{array}$ & $\begin{array}{l}0.028^{\star} \\
(0.013)\end{array}$ & $\begin{array}{l}-0.021 \\
(0.016)\end{array}$ \\
\hline Konstanta & $\begin{array}{l}3.058^{\star * *} \\
(0.406)\end{array}$ & $\begin{array}{l}4.107^{\star * *} \\
(0.605)\end{array}$ & $\begin{array}{l}3.318^{* * *} \\
(0.382)\end{array}$ & $\begin{array}{l}4.259^{\star * *} \\
(0.491)\end{array}$ \\
\hline $\mathrm{N}$ & 99 & 99 & 99 & 99 \\
\hline $\mathrm{F}$ & $31.016^{* * *}$ & $6.270^{* * *}$ & $29.623^{* * *}$ & $20.125^{* * *}$ \\
\hline Prilagođeni R na kvadrat & 0.786 & 0.392 & 0.778 & 0.701 \\
\hline
\end{tabular}

Napomena: Koeficijenti i standardne pogreške u zagradama. Statistička značajnost $\mathrm{p}<0.05^{*}, \mathrm{p}<0.01^{\star *}$, $\mathrm{p}<0.001^{* * *}$ 
Tablica 14. Linearni regresijski modeli postotka za različite političke opcije na parlamentarnim izborima 2020. godine (zavisna varijabla je prirodni logaritam izvorne zavisne varijable)

\begin{tabular}{|c|c|c|c|c|}
\hline & $\begin{array}{l}\text { HDZ } 2020 . \\
\text { god. } \\
(\ln )\end{array}$ & $\begin{array}{l}\text { SDP } 2020 . \\
\text { god. } \\
(\ln )\end{array}$ & $\begin{array}{c}\text { Desnica } \\
\text { 2020. god. } \\
\text { (HDZ, Most } \\
\text { i DP) } \\
\text { (ln) } \\
\end{array}$ & $\begin{array}{c}\text { Ljevica } \\
\text { 2020. god. } \\
\text { (SDP i } \\
\text { Možemo!) } \\
(\ln ) \\
\end{array}$ \\
\hline \multicolumn{5}{|l|}{ Naslijeđe Jugoslavije } \\
\hline $\begin{array}{l}\text { Udio uzdržavanog stanovništva } 1991 . \\
\text { godine }\end{array}$ & $\begin{array}{l}0.021^{\star} \\
(0.008)\end{array}$ & $\begin{array}{l}-0.018 \\
(0.014)\end{array}$ & $\begin{array}{l}0.017^{\star} \\
(0.008)\end{array}$ & $\begin{array}{l}-0.021 \\
(0.014)\end{array}$ \\
\hline $\begin{array}{l}\text { Udio industrijskih radnika u ukupnom } \\
\text { stanovništvu 1991. godine }\end{array}$ & $\begin{array}{l}-0.020^{* *} \\
(0.007)\end{array}$ & $\begin{array}{l}0.036^{* *} \\
(0.012)\end{array}$ & $\begin{array}{l}-0.023^{* *} \\
(0.007)\end{array}$ & $\begin{array}{l}0.034^{* *} \\
(0.012)\end{array}$ \\
\hline $\begin{array}{l}\text { Udio Srba u ukupnom stanovništvu } 1991 . \\
\text { godine }\end{array}$ & $\begin{array}{c}-0.007^{* *} \\
(0.002)\end{array}$ & $\begin{array}{l}0.011^{* *} \\
(0.004)\end{array}$ & $\begin{array}{l}-0.005^{*} \\
(0.002)\end{array}$ & $\begin{array}{l}0.012^{\star *} \\
(0.004)\end{array}$ \\
\hline $\begin{array}{l}\text { Udio ateista i nevjernika u ukupnom } \\
\text { stanovništvu 1991. godine }\end{array}$ & $\begin{array}{c}-0.091^{\star * *} \\
(0.012)\end{array}$ & $\begin{array}{l}0.110^{\star * *} \\
(0.021)\end{array}$ & $\begin{array}{c}-0.089^{* * *} \\
(0.011)\end{array}$ & $\begin{array}{l}0.109^{* * *} \\
(0.020)\end{array}$ \\
\hline $\begin{array}{l}\text { Udio stanovništva s fakultetskom } \\
\text { diplomom 1991. godine }\end{array}$ & $\begin{array}{c}0.023 \\
(0.013) \\
\end{array}$ & $\begin{array}{l}-0.017 \\
(0.023) \\
\end{array}$ & $\begin{array}{c}0.022 \\
(0.012) \\
\end{array}$ & $\begin{array}{l}-0.018 \\
(0.022) \\
\end{array}$ \\
\hline \multicolumn{5}{|l|}{ Tranzicija od 1991. do 2011. godine } \\
\hline $\begin{array}{l}\text { Promjena u udjelu uzdržavanog } \\
\text { stanovništva od 1991. do 2011. godine }\end{array}$ & $\begin{array}{l}0.018^{\star *} \\
(0.006)\end{array}$ & $\begin{array}{l}-0.015 \\
(0.011)\end{array}$ & $\begin{array}{c}0.012 \\
(0.006)\end{array}$ & $\begin{array}{l}-0.018 \\
(0.011)\end{array}$ \\
\hline $\begin{array}{l}\text { Promjena u udjelu industrijskih radnika } \\
\text { od 1991. do 2011. godine }\end{array}$ & $\begin{array}{l}-0.016 \\
(0.008)\end{array}$ & $\begin{array}{l}0.040^{* *} \\
(0.015)\end{array}$ & $\begin{array}{l}-0.022^{* *} \\
(0.008)\end{array}$ & $\begin{array}{l}0.039^{* *} \\
(0.014)\end{array}$ \\
\hline $\begin{array}{l}\text { Promjena u udjelu Srba od 1991. do } 2011 . \\
\text { godine }\end{array}$ & $\begin{array}{l}-0.008^{*} \\
(0.003)\end{array}$ & $\begin{array}{l}0.013^{*} \\
(0.006)\end{array}$ & $\begin{array}{l}-0.005 \\
(0.003)\end{array}$ & $\begin{array}{l}0.011^{*} \\
(0.006)\end{array}$ \\
\hline $\begin{array}{l}\text { Promjena u udjelu ateista i nevjernika od } \\
\text { 1991. do 2011. godine }\end{array}$ & $\begin{array}{c}-0.137^{* * *} \\
(0.019)\end{array}$ & $\begin{array}{c}0.129^{* * *} \\
(0.034)\end{array}$ & $\begin{array}{c}-0.141^{\star * *} \\
(0.018)\end{array}$ & $\begin{array}{c}0.125^{\star * *} \\
(0.033)\end{array}$ \\
\hline $\begin{array}{l}\text { Promjena u udjelu stanovništva s } \\
\text { fakultetskom diplomom od 1991. do } 2011 . \\
\text { godine }\end{array}$ & $\begin{array}{l}-0.011 \\
(0.010)\end{array}$ & $\begin{array}{l}-0.005 \\
(0.017)\end{array}$ & $\begin{array}{l}-0.007 \\
(0.010)\end{array}$ & $\begin{array}{c}0.019 \\
(0.017)\end{array}$ \\
\hline \multicolumn{5}{|l|}{ Naslijeđe ratova } \\
\hline $\begin{array}{l}\text { Broj invalida Domovinskog rata na tisuću } \\
\text { stanovnika (Popis stanovništva iz } 2001 . \\
\text { godine) }\end{array}$ & $\begin{array}{l}0.007^{\star} \\
(0.003)\end{array}$ & $\begin{array}{c}-0.015^{* *} \\
(0.005)\end{array}$ & $\begin{array}{l}0.009^{* *} \\
(0.003)\end{array}$ & $\begin{array}{c}-0.015^{\star *} \\
(0.005)\end{array}$ \\
\hline $\begin{array}{l}\text { Broj invalida Drugog svjetskog rata na } \\
\text { tisuću stanovnika (Popis stanovništva iz } \\
\text { 2001. godine) }\end{array}$ & $\begin{array}{c}0.014 \\
(0.013)\end{array}$ & $\begin{array}{l}-0.003 \\
(0.022)\end{array}$ & $\begin{array}{c}0.004 \\
(0.012)\end{array}$ & $\begin{array}{l}-0.008 \\
(0.022)\end{array}$ \\
\hline Konstanta & $\begin{array}{c}2.976^{* * *} \\
(0.379)\end{array}$ & $\begin{array}{c}3.696^{* * *} \\
(0.672)\end{array}$ & $\begin{array}{c}3.527^{* * *} \\
(0.369)\end{array}$ & $\begin{array}{c}3.846^{* * \star} \\
(0.661)\end{array}$ \\
\hline $\mathrm{N}$ & 99 & 99 & 99 & 99 \\
\hline $\mathrm{F}$ & $25.451^{\star * *}$ & $11.544^{\star * *}$ & $24.908^{\star * *}$ & $12.794^{* * *}$ \\
\hline Prilagođeni R na kvadrat & 0.750 & 0.564 & 0.745 & 0.591 \\
\hline
\end{tabular}

Napomena: Koeficijenti i standardne pogreške u zagradama. Statistička značajnost $\mathrm{p}<0.05^{\star}, \mathrm{p}<0.01^{\star *}$, $\mathrm{p}<0.001^{* * *}$ 
Tablica 15. Logistički regresijski modeli za pripadnost "crnoj Hrvatskoj" (vidi kartu 3 i 4 )

\begin{tabular}{|c|c|c|c|c|}
\hline & $\begin{array}{c}\text { Crna } \\
\text { Hrvatska } \\
\text { (verzija 1) } \\
\end{array}$ & $\begin{array}{l}\text { Omjeri } \\
\text { izgleda }\end{array}$ & $\begin{array}{c}\text { Crna } \\
\text { Hrvatska } \\
\text { (verzija 2) } \\
\end{array}$ & $\begin{array}{l}\text { Omjeri } \\
\text { izgleda }\end{array}$ \\
\hline \multicolumn{5}{|l|}{ Naslijeđe Jugoslavije } \\
\hline $\begin{array}{l}\text { Udio uzdržavanog stanovništva } 1991 . \\
\text { godine }\end{array}$ & $\begin{array}{c}0.209 \\
(0.198)\end{array}$ & 1.232 & $\begin{array}{l}-0.085 \\
(0.147)\end{array}$ & 0.918 \\
\hline $\begin{array}{l}\text { Udio industrijskih radnika u ukupnom } \\
\text { stanovništvu 1991. godine }\end{array}$ & $\begin{array}{c}-0.345^{*} \\
(0.188)\end{array}$ & 0.708 & $\begin{array}{l}-0.188 \\
(0.117)\end{array}$ & 0.829 \\
\hline $\begin{array}{l}\text { Udio Srba u ukupnom stanovništvu } 1991 . \\
\text { godine }\end{array}$ & $\begin{array}{l}-0.182^{*} \\
(0.085)\end{array}$ & 0.834 & $\begin{array}{l}-0.107 \\
(0.067)\end{array}$ & 0.899 \\
\hline $\begin{array}{l}\text { Udio ateista i nevjernika u ukupnom } \\
\text { stanovništvu 1991. godine }\end{array}$ & $\begin{array}{c}0.671^{*} \\
(0.315)\end{array}$ & 0.511 & $\begin{array}{l}-0.179 \\
(0.260)\end{array}$ & 0.836 \\
\hline $\begin{array}{l}\text { Udio stanovništva s fakultetskom } \\
\text { diplomom 1991. godine }\end{array}$ & $\begin{array}{r}0.174 \\
(0.273) \\
\end{array}$ & 1.190 & $\begin{array}{l}-0.295 \\
(0.352) \\
\end{array}$ & 0.745 \\
\hline \multicolumn{5}{|l|}{ Tranzicija od 1991. do 2011. godine } \\
\hline $\begin{array}{l}\text { Promjena u udjelu uzdržavanog } \\
\text { stanovništva od 1991. do 2011. godine }\end{array}$ & $\begin{array}{c}0.097 \\
(0.134)\end{array}$ & 1.102 & $\begin{array}{l}-0.071 \\
(0.130)\end{array}$ & 0.931 \\
\hline $\begin{array}{l}\text { Promjena u udjelu industrijskih radnika } \\
\text { od 1991. do 2011. godine }\end{array}$ & $\begin{array}{c}-0.390+ \\
(0.228)\end{array}$ & 0.677 & $\begin{array}{c}-0.254+ \\
(0.152)\end{array}$ & 0.776 \\
\hline $\begin{array}{l}\text { Promjena u udjelu Srba od 1991. do } 2011 . \\
\text { godine }\end{array}$ & $\begin{array}{l}-0.214 \\
(0.138)\end{array}$ & 0.807 & $\begin{array}{l}-0.180 \\
(0.134)\end{array}$ & 0.835 \\
\hline $\begin{array}{l}\text { Promjena u udjelu ateista i nevjernika od } \\
\text { 1991. do 2011. godine }\end{array}$ & $\begin{array}{l}-0.839 \\
(0.555)\end{array}$ & 0.432 & $\begin{array}{l}-0.571 \\
(0.538)\end{array}$ & 0.565 \\
\hline $\begin{array}{l}\text { Promjena u udjelu stanovništva s } \\
\text { fakultetskom diplomom od 1991. do } 2011 . \\
\text { godine }\end{array}$ & $\begin{array}{l}-0.094 \\
(0.181)\end{array}$ & 0.911 & $\begin{array}{c}0.087 \\
(0.407)\end{array}$ & 1.091 \\
\hline \multicolumn{5}{|l|}{ Naslijeđe ratova } \\
\hline $\begin{array}{l}\text { Broj invalida Domovinskog rata na tisuću } \\
\text { stanovnika (Popis stanovništva iz } 2001 . \\
\text { godine) }\end{array}$ & $\begin{array}{l}0.279^{\star *} \\
(0.101)\end{array}$ & 1.322 & $\begin{array}{l}0.341^{\star} \\
(0.141)\end{array}$ & 1.407 \\
\hline $\begin{array}{l}\text { Broj invalida Drugog svjetskog rata na } \\
\text { tisuću stanovnika (Popis stanovništva iz } \\
\text { 2001. godine) }\end{array}$ & $\begin{array}{c}0.472 \\
(0.304)\end{array}$ & 1.604 & $\begin{array}{c}0.211 \\
(0.277)\end{array}$ & 1.235 \\
\hline Konstanta & $\begin{array}{l}-8.343 \\
(9.538)\end{array}$ & 0.000 & $\begin{array}{c}4.747 \\
(6.718)\end{array}$ & 115.229 \\
\hline $\mathrm{N}$ & 99 & & 99 & \\
\hline Postotak ispravno klasificiranih & 88.9 & & 84.8 & \\
\hline Cox \& Snell R na kvadrat & 0.572 & & 0.443 & \\
\hline
\end{tabular}

Napomena: Koeficijenti i standardne pogreške u zagradama. Statistička značajnost $\mathrm{p}<0.05^{*}, \mathrm{p}<0.01^{* *}$, $\mathrm{p}<0.001^{* * *},+\mathrm{p}<0.1$ 


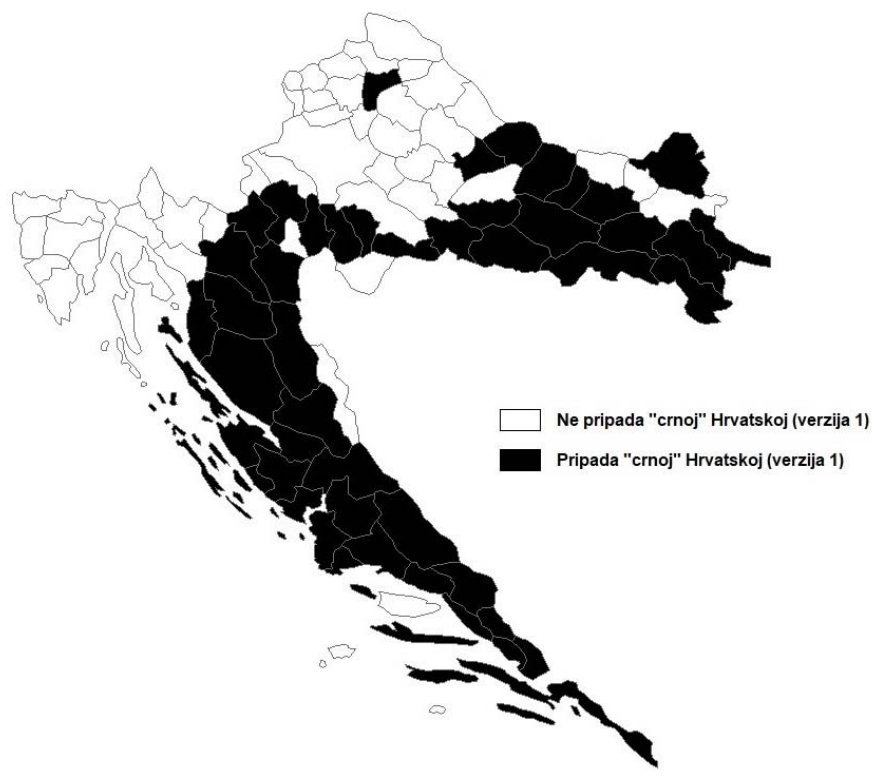

Karta 3. "Crna" Hrvatska (verzija 1)

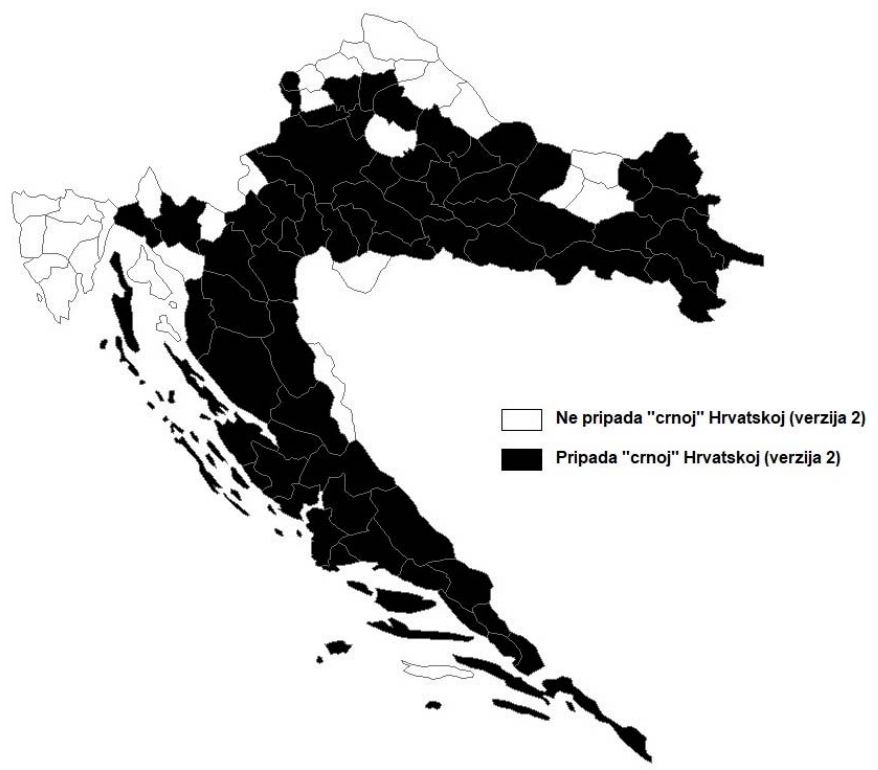

Karta 4. "Crna" Hrvatska (verzija 2) 